\title{
ECONOMICS OF THE GENERATION AND MANAGEMENT OF MUNICIPAL SOLID WASTE
}

David N. Beede

David E. Bloom

Working Paper No. 5116

\section{NATIONAL BUREAU OF ECONOMIC RESEARCH 1050 Massachusetts Avenue \\ Cambridge, MA 02138 \\ May 1995}

The authors appreciate support provided by The World Bank for the preparation of this paper. The authors also wish to thank two anonymous referees, Carl Bartone, Mark Gersovitz, Arik Levinson, and Moshe Syrquin for helpful suggestions and comments. This paper is part of NBER's research program in Health Care. Any opinions expressed are those of the authors and not those of the Department of Commerce, The World Bank, or the National Bureau of Economic Research.

(ㅇ 1995 by David N. Beede and David E. Bloom. All rights reserved. Short sections of text, not to exceed two paragraphs, may be quoted without explicit permission provided that full credit, including (c) notice, is given to the source. 


\title{
ECONOMICS OF THE GENERATION AND MANAGEMENT OF MUNICIPAL SOLID WASTE
}

\begin{abstract}
This paper examines the generation and management of municipal solid waste (MSW) through the lens of economics. We estimate that the global burden of MSW amounted to 1.3 billion metric tons in 1990 , or 0.67 kilograms of waste per person per day. Industrial countries account for a disproportionate share of the world's MSW relative to their share of world population, while developing countries account for a disproportionate share of the world's MSW relative to their share of world income. Cross-country and time-series analyses reveal that MSW generation is positively associated, but inelastic, with respect to per capita income, and positively associated and unit elastic with respect to population size.

Practices for collecting, processing, and disposing of MSW vary widely across countries, generally in accord with the nature of the waste stream and key features of the environmental and economic context. However, the least efficient practices tend to be found in developing countries, where MSW poses serious threats to local environmental quality and public health. Although considerable evidence indicates that the generation and management of MSW is sensitive to income and price variables, natural incentives to overuse common property and the presence of intergenerational externalities both suggest that private economic behavior will not yield socially optimal outcomes in this area. Community intervention, which may take a variety of forms, may thereby promote the social good, with evidence accumulating that favors arrangements involving the participation of private firms. The average cost of MSW management is likely to grow faster than the pace of urbanization if urbanization outpaces the development of transportation infrastructures. Our calculations also suggest that improvements now in the handling of hazardous MSW will be far less expensive in discounted terms than undoing in the future the damage being caused by current handling practices. Addressing these issues from a rational societal perspective will become increasingly urgent in the future, especially in the developing countries, where urbanization is accelerating and whose MSW we project will increase at an annual rate of 2.7 percent through the year 2010.
\end{abstract}

David N. Beede

U.S. Department of Commerce

Room 4858 HCHB

Washington, DC 20230
David E. Bloom

Department of Economics

Columbia University

New York, NY 10027

and NBER 


\section{Economics of the Generation and Management of Municipal Solid Waste}

The United Nations Conference on Environment and Development, held in Rio de Janeiro in June 1992, focused world attention on the undesirable side-effects of economic advancement on the environment. Among the many problems addressed, the two that seemed to garner the most attention were climate change caused by the accumulation of greenhouse gases and depletion of the ozone layer caused by the emission of chlorofluorocarbons. Although neither problem is well understood in scientific or economic terms, both appear to be developing slowly and are not expected to unfold significantly until well into the future.

Increased levels of municipal solid waste (MSW) are another undesirable by-product of population growth and economic development. Although MSW does not have the catastrophic potential of either global warming or stratospheric ozone depletion, it has long posed threats to environmental quality and human health that are reasonably well understood and are typically of great local and immediate concern. Accelerating urbanization accompanied by increasing per capita incomes have led to rapid increases in MSW generation that have dramatically expanded the burden on local governments in many developing countries to collect, process, and dispose of MSW in socially efficient ways.

The purpose of this article is to describe and analyze, through an economics lens, the generation and management of municipal solid waste. The paper also explores the implications of current MSW trends, practices, and policies for future environmental quality 
and human welfare. While the analysis focuses mainly on developing countries, we also devote some attention to the example of the United States, for which relevant data are more readily available.

Through a combination of economic reasoning, data analysis, case studies, and literature review we endeavor to make three main sets of points. First, the world's population is generating substantial quantities of MSW. Although a sizable portion of MSW is collected and disposed of through controlled incineration or burial in sanitary landfills, much continues to be burned openly or dumped haphazardly, especially in developing countries. These latter practices are putting increasing pressure on land, air, and water quality and threatening human health, problems that will be further exacerbated by projected increases in total MSW generation. Our calculations suggest that some improvements in the handling of MSW now would be less expensive (in discounted terms) than undoing in the future the damage to the environment and to human health caused by current handling practices.

Second, although MSW represents an undesirable by-product of certain economic activities, it is generally not devoid of resource value. Some of this value is captured through private economic activity, for example, informal sector scavenging and recycling practiced throughout the developing world, and through community-sponsored recycling systems and conversion of MSW into energy or compost or both. Many studies are under way throughout the world to determine whether further value can be economically captured from MSW. 
Third, because the benefits of MSW disposal extend beyond the households and firms incurring the costs of disposal, community intervention to influence the scope or intensity of various MSW management practices may promote the social good. Intervention can take many forms, for example, the direct provision of MSW collection, transport, and disposal services; the regulation of MSW management activities; the establishment of various taxes and subsidies; and the funding of research and development on the handling of MSW. Evidence is, however, accumulating that favors arrangements involving some private participation in MSW management.

Section I of this paper discusses the definition and measurement of MSW and describes cross-national and time series patterns in its generation. Section II describes the principal technologies for managing MSW and reviews selected economic issues. Section III discusses private economic behavior in the area of MSW generation and management and explores the role of government intervention. Section IV presents brief case studies of MSW management in several developing-country cities and in the United States. Section V presents evidence that popular dissatisfaction with MSW management is higher in developing than industrial countries, which several more rapidly growing developing countries appear to be addressing in innovative ways. 


\section{Background}

\section{A. Definition and Measurement of Municipal Solid Waste}

Municipal solid waste (MSW) consists of all solid wastes generated in a community except for industrial and agricultural wastes (Tchobanoglous, Theisen, and Vigil 1993, p. 41) and generally includes discarded durable and nondurable goods; containers and packaging; food scraps; yard trimmings; miscellaneous inorganic debris, including household hazardous wastes (for example, aerosol cans, leftover paint, household and automobile batteries, and pesticides) (U.S. Environmental Protection Agency 1992, p. 1-2 - 1-4), and often construction and demolition debris and sludges and ashes generated by sewage treatment and MSW incinerators (Tchobanoglous, Theisen, and Vigil 1993, p. 41). ${ }^{1}$ Sources of MSW include households; commercial enterprises and industrial firms (for example, food market and office paper wastes); and institutions such as schools, transportation terminals, and hospitals (U.S. Environmental Protection Agency 1992, pp. 1-2 - 1-4 and 5-3). MSW in developing countries is often disposed of with ash, human wastes (where sewage systems do not reach substantial portions of the population; Mensah and Whitney 1991, p. 157), medical waste (Bartone, Bernstein, and Wright 1990, p. 3), and industrial waste (Benavides 1992), sometimes making MSW in developing countries more harmful to human and ecological health than it is in industrial countries.

MSW can be divided into recycled and nonrecycled materials. Recycled materials consist of by-products of production or consumption activities that are gathered, refined, and used as inputs for production activities. Examples are discarded aluminum soft drink cans 
that are melted down to create new cans, food and yard wastes that are composted and used to enhance soil fertility, and old newspapers and plastic bottles that are burned to produce electricity. The nonrecycled portion of MSW consists of by-products that must generally be removed from their site of generation lest they interfere with production and consumption activities by attracting vermin and flies, inhibiting mobility, clogging drains, emitting unpleasant odors, and so on. The division of MSW between recycled and nonrecycled materials depends on the nature and cost of available production, consumption, recycling, and disposal technologies, as well as on government regulations, all of which can vary widely across economic settings.

Economic research on MSW is impeded by a paucity of data and by imperfections in the data that do exist. Time series data on MSW generation, recovery, and discard rates exist for only a few countries. Like most variables used in cross-national empirical research, few country estimates of MSW are derived using common definitions, data sources, or estimation techniques. Most existing country estimates of MSW generation (and its composition) are based on either the sampling method or on materials balance analysis. The sampling method involves sorting and weighing samples of individual households' MSW (see, for example, the description of The Garbage Project at the University of Arizona in Rathje and Murphy 1993) and using the results to infer MSW generation rates for a larger group of households. This method is relatively labor-intensive, and therefore prohibitively expensive in some contexts (U.S. Environmental Protection Agency 1992, p. 1-4). In contrast, materials balance analysis estimates MSW generation by weight as the tonnage of 
nondurable goods consumption plus estimated discards of nondurable goods. ${ }^{2}$ MSW generation rates estimated by the United States Environmental Protection Agency using materials balance analysis appear to be broadly consistent with estimates obtained using the sampling method (U.S. Environmental Protection Agency, pp. 7-4 - 7-7).

\section{B. Cross-National and Time Series Patterns in the Generation of MSW.}

Issues of data quality and comparability notwithstanding, exploring the covariates of published data on MSW generation is instructive. The first column of table 1 reports estimated income and population elasticities of MSW generation (that is, the average percentage changes in MSW generation associated with one percent increases in GDP per capita and population, respectively). ${ }^{3}$ The elasticity estimates are based on thirty-six countries for which the World Resources Institute published data on daily per capita MSW generation. ${ }^{4}$ The MSW generation rates range from 0.5 kilograms for Mozambique (which had estimated per capita GDP of $\$ 620$ in 1990$)$ to 1.9 kilograms for Australia $(\$ 17,000$ estimated per capita GDP in 1990). ${ }^{5}$

The estimates indicate that a one percent increase in per capita income is associated with a 0.34 percent increase in total MSW generation (significantly different from zero), and that a one percent increase in population is associated with a 1.04 percent increase in MSW (not significantly different from 1.0). ${ }^{6}$ If the population elasticity is constrained to equal 1.0 , which cannot be rejected at a 95 percent level of confidence, the income elasticity remains at 0.34 and is significantly less than $1.0 .^{7}$ These results suggest that MSW is 
responsive to both income and population but more responsive to population than to income.

Along with the published MSW data, we use the regression coefficients and data on per capita GDP and population in 1990 for 149 countries and territories not included in the regression to construct an estimate of global MSW generation. ${ }^{8,9}$ Table 2 reports the results of this exercise, which suggest that the world generated approximately 1.3 billion metric tons of MSW in 1990, or an average of two-thirds of a kilogram per person per day. This aggregate tonnage exceeded the world's combined output of wheat and rice in 1990 (1.1 billion metric tons; The World Almanac 1993, p. 125).

The last column of Table 2 indicates that daily per capita generation of MSW is much lower in developing countries than in developed countries. Table 2 also indicates that highincome economies account for a disproportionate share of MSW generation on a population basis (that is, they account for less than one-sixth of the world's population but generate more than one-fourth of the world's MSW), while developing countries account for a disproportionate share of MSW generation on an income basis (that is, they account for less than half of the world's combined GDP but nearly three-fourths of the world's MSW).

Assuming that national GDP growth rates for the 1980s hold steady into the future, that population growth proceeds according to World Bank projections, ${ }^{10}$ and that the multivariate relationship reported in the first column of table 1 remains stable, global MSW generation is projected to double between 1990 and 2019 (that is, an average annual growth rate of about 2.4 percent). However, per capita MSW generation is not projected to double until 2049 (that is, an average annual growth rate of 1.2 percent). ${ }^{11}$ In all likelihood these 
doubling times will be even longer because of materials substitution (for example, the use of aluminum and plastic instead of steel and glass in containers and packaging) and technological innovation (for example, the redesign of containers to use less material) that have historically accompanied economic growth. ${ }^{12}$

We also explored trends and patterns in MSW generation across jurisdictions within China and the United States (see table 1). Using data for 45 cities in China in 1990 and data for 33 states in the United States in 1992, we found results very similar to those for the cross-country analysis: income elasticities that are significantly less than 1.0 and population elasticities that are extremely close to 1.0. In other words, we cannot reject the hypotheses of unit population elasticity and income inelasticity. ${ }^{13}$

Trends and patterns in MSW generation can also be explored using available time series data for both Taiwan and the United States (see Table 3). For Taiwan the estimated income elasticity of MSW generation is 0.59 , and the population elasticity is 1.63 (not significantly different from 1.0 ). If the population elasticity is constrained to be 1.0 , which cannot be rejected at a 95 percent level of confidence, the estimated income elasticity rises to 0.72 but remains significantly less than 1.0. For the United States the estimated income elasticity of MSW generation is 0.86 and the population elasticity is 0.63 . If the population elasticity is constrained to be 1.0 (which cannot be rejected at a 95 percent level of confidence), the income elasticity falls to 0.63 and is significantly less than 1.0 (notably, the estimated income elasticity in the time series restricted regression is very close to the crossstate income elasticity shown in table 1). These estimates for Taiwan and the United States 
suggest somewhat greater responsiveness of MSW to income per capita than the cross-country estimates noted earlier. Nevertheless, MSW generation appears to be inelastic with respect to per capita income and unit elastic with respect to population. ${ }^{14}$ 


\section{Technologies for Managing MSW}

Most systems for managing MSW have three basic components: collection and transport, processing, and disposal. ${ }^{15}$ The purpose of collection and transport is to gather and remove MSW from its point of generation to safeguard public health, limit congestion, and preclude unpleasant odors and aesthetically offensive scenes. Processing involves transforming the physical characteristics of MSW by recycling, composting, burning, or compacting, in order to reduce the threat it poses to human health and ecosystems, improve its disposability, and possibly capture value from the waste. The goal of disposal is isolation and containment of the residual waste that is left after processing.

A range of options are available for each component of MSW management. Ideally, cost-benefit comparisons will guide choices among the options. Such comparisons will reflect a variety of technical parameters that define the physical characteristics of specific MSW streams and local geography, for example, climate, suburbanization, and transportation infrastructure. They will also reflect key economic parameters, such as the relative prices of labor, plant and equipment, materials, energy, and land, which can vary considerably both within and between countries.

The valuation of some costs and benefits of MSW management options is relatively clear-cut, such as out-of-pocket collection and transport expenses and revenues from the sale of recyclable materials, compost, and energy. However, one must also account for some costs and benefits that are perhaps less obvious, such as the opportunity costs of land (for transfer stations, processing facilities, or landfills) and household labor (especially if 
households are expected to sort their waste or transport it to a central collection point), and savings from avoided disposal costs when new technologies are implemented. Further complexities arise in valuing multidimensional outcomes, some of which are not easily expressed in pecuniary terms, such as improvements (or deteriorations) in public health and in the aesthetic quality of air, water, or land. In addition, cost-benefit comparisons must reflect any complementarities between different MSW management options, for example, the cost of producing agricultural-quality compost may fall sharply if households separate their compostable and noncompostable waste. The comparisons must also account for the time value of resources, which requires the choice of a discount rate, often a controversial issue.

Although estimating reliable monetary values for all costs and benefits is often not feasible, the framework of cost-benefit analysis can nonetheless provide useful guidance for decisionmaking and evaluation. The remainder of this section deals with four factors that generally weigh heavily in cost-benefit comparisons of alternative MSW management options: relative costs of labor and other production factors, physical characteristics of MSW, efficient scales of operation, and nonpecuniary costs and benefits of MSW management.

\section{A. Relative Costs of Labor and Other Production Factors}

Compared with industrial countries, in developing countries unskilled labor is relatively abundant, skilled labor and physical capital are relatively scarce, and infrastructure is often limited. As a consequence, the cost of unskilled labor relative to the cost of skilled 
labor, land, and capital (including equipment, buildings, vehicles, fuel, materials, and spare parts) is generally lower in developing countries than in industrial countries. Although capital-intensive MSW management techniques, which are typically human capital- and infrastructure-intensive as well, may be economically efficient in industrial countries, they are less likely to be optimal choices in developing countries. ${ }^{16}$

Labor-intensive collection and processing of recyclable materials is found throughout the developing world. It can involve households bringing their recyclables to redemption centers (Cointreau and others 1984, p. 8), small-scale entrepreneurs going door-to-door to purchase recyclables, ${ }^{17} \mathrm{MSW}$ collection workers and informal sector scavengers rummaging through household wastes put out for collection, ${ }^{18}$ or informal sector scavengers sifting through MSW at transfer stations and final dumpsites. ${ }^{19}$ Often the privately run businesses that purchase, clean, sort, and sell recyclables in bulk to other middlemen or directly to factories are also highly labor-intensive (see Bennett and others 1992, pp. 3-22 and Sicular 1992 for descriptions the recycling industry in Jakarta). The practice of scavenging may also have implications for the adoption of other MSW management techniques, as in Jakarta, where scavengers regularly tore apart MSW that was machine-compacted and baled by the city government's MSW sanitation agency (Bartone, Bernstein, and Wright 1990, pp. 18-19).

In contrast, the collection and processing of recyclable materials in industrial countries are considerably more capital-intensive than is the case in most developing countries. Nevertheless, a broad range of capital intensities of recycling activities exists 
within the United States (and presumably within other industrial countries) ${ }^{20}$ The most capital-intensive method is mixed MSW collection, in which MSW is collected and delivered to a facility that uses complex equipment to extract recyclable materials, with the remainder often used to make fuels for electricity generating incinerators.

A somewhat less capital-intensive system for recycling is the collection of old newspapers and commingled glass, metal, and plastic materials. Generally this method requires special trucks that have two compartments, one for newspapers and the other for the rest of the recyclable materials. Households and firms perform the initial separation of recyclable materials, and the process is refined at materials recovery facilities, which range in capital-intensity from highly automated systems that use magnets to extract ferrous metals, air classifiers (which use blowers to separate light materials, such as plastics, by weight), and eddy-current separators to extract aluminum (magnets above a conveyor belt that induce an opposing magnetic field in aluminum on the belt and push it off into a separate bin), to a "low-tech" conveyor belt that transports recyclable materials past workers who pick and sort the materials.

Finally, among the least capital-intensive, and hence most labor-intensive, recycling systems in use in industrial countries is one in which either households sort and separate each type of recyclable material (paper, aluminum, steel cans, different types of plastic, glass by color) or workers sort commingled recyclable materials as they collect it. They place each type of waste in its own compartment in the collection truck. Alternatively, households transport separated recyclable materials to drop-off centers that are either containers scattered 
throughout a community or staffed facilities or to bottle buy-back centers in the case of beverage container deposit systems. All capital-intensive recycling systems require that materials be made more dense using shredders, balers, and pulverizers to reduce transport costs.

Labor-intensive aerobic composting facilities may be more appropriate in developing countries than the highly automated facilities (aerobic or anaerobic) typical of industrial countries. In the most extreme cases, workers may hand sort nonrecyclable biodegradable materials from noncompostable materials, build and turn windrows (piles of biodegradable materials that are turned periodically to expose them to oxygen and control the temperature to promote biodegradation), and screen and bag finished compost using only simple hand tools. ${ }^{21}$ Capital-intensive composting projects in developing countries often fail, for example, in Lagos (Cointreau-Levine 1994, p. 29), or may be converted to relatively more labor-intensive facilities, as in a number of cities in India.

The substitution of labor for capital in the management of MSW is not, however, without limits. ${ }^{22}$ For example, land disposal of MSW in developing countries usually consists of discarding MSW in open dumps (Bartone and Bernstein 1993, pp. 43-4). This practice is insufficiently capital-intensive, as siting landfills in areas with a high water table or constructing them without clay liners may lead to the formation of leachate (liquid that accumulates dissolved or suspended materials as it permeates the MSW in landfills), which may seep out of the landfill and pollute groundwater and surface water. To the extent that hazardous waste is present in the MSW stream, leachate may lead to serious contamination 
of the water supply, which could adversely affect agriculture and have costly health implications for both current and future generations of people.

Public cleansing of streets and open areas is critically important in areas where MSW is indiscriminately dumped alongside roads. Inefficient collection techniques exacerbate this problem. For example, in the medina (old quarter) of Moroccan cities, residents use the streets to discard food waste, where the following morning crews sweep up the waste and collect it in wicker baskets. Some portion of the collected waste spills out of the baskets back onto the streets (Ohnesorgen 1993, p. 12). Uncovered collection trucks, often used in Shanghai, also spill some of their loads back onto streets (Ward and Li 1993, p. 31-32). Given that the cost per metric ton of cleaning MSW off streets in developing countries is estimated to be between two and three times that of collection (Cointreau-Levine 1994, p. 42), using more costly collection equipment that reduces spillage, for example, covered trucks, would likely be more efficient.

\section{B. Physical Characteristics of $M S W$}

The physical characteristics of MSW help determine its processing costs (net of any resource value) and its residual disposal costs. Key characteristics include its density (which helps determine required landfill capacity and collection and transport equipment needs), energy content, biodegradable content, moisture content, and the carbon to nitrogen ratio of the biodegradable portion of MSW.

Table 4 reports data on the average composition (by weight) of MSW for several 
cities in developing countries and for the United States. ${ }^{23}$ Food waste represents the largest portion of MSW in the developing country cities, but is a relatively small component of MSW in the United States. This difference reflects relatively high consumption of unprocessed vegetables, fruits, and meats in cities in developing countries, which leads to relatively more discards of peels, bones, and other food wastes. ${ }^{24}$ By contrast, paper accounts for a much smaller share of MSW in the developing country cities, reflecting relatively less per capita consumption of packaged goods, office paper, newspapers, and magazines than in the United States. ${ }^{25}$ The higher food waste content of MSW in the developing country cities is more or less offset by the lower paper content, resulting in comparable biodegradable content. Biodegradable materials are important to the economics of MSW management because they may be converted through microbial activity into either methane, which can be captured and used as a fuel, or into compost. ${ }^{26}$

The carbon to nitrogen $(\mathrm{C} / \mathrm{N})$ ratio of the biodegradable portion of MSW is an important determinant of the speed (and therefore the cost) of composting. The optimal $\mathrm{C} / \mathrm{N}$ ratio of 25 to 1 is substantially exceeded for all the locations reported in table 4 except Jakarta and Dar es Salaam. Lower $\mathrm{C} / \mathrm{N}$ ratios can be achieved, though at a cost, by blending MSW with sewage sludge or certain animal manures (for example, chicken or cow) that have relatively low $\mathrm{C} / \mathrm{N}$ ratios (Tchobanoglous, Theisen, and Vigil 1993, pp. 686-89). However, if the primary goal is energy recovery by using anaerobic digestion of organic materials, then too low a $\mathrm{C} / \mathrm{N}$ ratio (less than 10 to 15 ) can lead to excessive generation of ammonia, which kills the anaerobic bacteria that generate methane (Tchobanoglous, Theisen, and Vigil 1993, 
pp. 702 and 704).

The moisture content of biodegradable MSW is also an important factor in the economics of collecting, composting, and incinerating MSW. Compacting trucks designed for MSW collection in the United States often perform poorly when loaded with the highmoisture MSW typically found in many developing countries (Bartone, Bernstein, and Wright 1990, pp. 18-19). High-moisture MSW also tends to clog windrow aeration machines, reducing the efficiency of the equipment.

The moisture content needed to achieve the most rapid conversion of MSW into compost is 50 to 60 percent (Tchobanoglous, Theisen, and Vigil 1993, p. 691). This exceeds the moisture content of biodegradable MSW for every location reported in table 4 (although MSW moisture content can vary considerably by season). While maintaining moisture content at a level that minimizes composting time helps to maximize throughput and thus keep average production costs down, it may also render MSW composting prohibitively costly in arid regions and in areas with water that is contaminated by salt, heavy metals, or other nonbiodegradable pollutants. ${ }^{27}$

Table 4 also indicates that the energy content of MSW in developing countries is relatively low, mainly because of its high moisture content. Incineration for volume reduction (which reduces landfill costs) and (perhaps) energy generation is impeded by moisture and is generally dealt with by adding fuel, thereby increasing the capital-intensity and reducing the cost-effectiveness of this processing option (Elkington and Shopley 1989, p. 19). 


\section{Efficient Scale of Operations}

As the average cost per ton of collecting, processing, or disposing of MSW generally varies with the amount of MSW being handled, the scale of operations may be crucial to the selection of cost-effective MSW management options. Average management costs per ton of MSW may decline as the scale of operations increases over some range (that is, there may be economies of scale in MSW management), for several reasons. First, MSW management facilities entail some fixed costs (that is, costs that are relatively invariant to the amount of MSW dealt with at the facility, within a specified range). These include compensation for workers in some occupations (for example, administrators, engineers, technicians, mechanics, salespersons) and the cost of plant and equipment, access roads to facilities, utilities (that is, water and electricity) hookups, and siting and licensing. MSW management options that are unskilled labor-intensive will tend to achieve their minimum average costs per ton at lower levels of capacity than physical and human capital-intensive options. ${ }^{28}$

Second, average costs of MSW management may decline as the amount of MSW handled increases because of the increased use of specialized workers or machines. For example, a relatively small but capital-intensive composting facility may use a single bulldozer or bucket loader for forming and turning windrows and for consolidating and moving composted material from the windrow area of the facility to the curing area. These are not the most efficient machines for turning windrows, however, because they compact the material and do not accomplish much mixing or aeration. The use of specialized windrow turning equipment may be more cost-effective at large capacity (that is, more than a few 
metric tons per day), capital-intensive facilities (Diaz, Savage, and Golueke 1994, pp. 10.20, 10.22-10.23).

Several geographic characteristics of metropolitan areas may have an impact on the degree to which there are economies of scale in MSW management. Households in sparsely populated rural areas are typically able to dispose of their MSW in ways that do not adversely affect their neighbors. For example, rural households may dump their MSW in nearby fields or wooded areas; they may burn their MSW; or they may compost the organic portion of their MSW. Urban households cannot exercise these options without either incurring great cost or burdening their neighbors. Urban areas thus require frequent and reliable MSW collection.

In addition to raising the concentration of MSW per square kilometer, urbanization also increases the cost of MSW management by leading to greater congestion and road damage. For example, low-income areas in developing country cities often have narrow or congested streets that cannot support large MSW collection trucks (Cointreau-Levine 1994, p. 16). Given such infrastructure, it may be cost-effective to provide collection service to low-income areas using communal containers to which residents bring their MSW. MSW management systems in Egypt, India, Indonesia, and the Philippines incorporate handcarts as the main method of door-to-door MSW collection in low-income neighborhoods. The MSW is often delivered to neighborhood bins or mini-transfer stations (Bartone, Bernstein, Wright 1990 , p. 18) where the wastes are collected by larger trucks for transport to final disposal facilities, perhaps via larger conventional transfer stations, if the transportation infrastructure 
is adequate (for example, if there are highways in good condition that link transfer stations to landfills). Because handcart collection requires relatively little in the way of capital investment compared with motorized vehicle collection, the minimum efficient scale of handcart collection is relatively small. If urbanization outpaces the development of transportation infrastructure, the average cost of MSW management will tend to rise.

Suburbanization can also raise the costs per ton of MSW collection and transport for two reasons. ${ }^{29}$ First, insofar as it is associated with rising land costs at the fringes of metropolitan areas, suburbanization may increase the cost of establishing new MSW management facilities. ${ }^{30}$ Second, suburbanization may increase the average distance that collection vehicles must travel from one collection site to the next. Greater travel distances increase the likelihood that a system of transfer stations would be judged cost-beneficial. If hauling distances to MSW processing or disposal facilities are greater than fifteen to twenty kilometers or travel time exceeds thirty minutes, delivering collected MSW to transfer stations where it can be consolidated into large loads that can be transported by tractor-trailer trucks, rail cars, or barges (Tchobanoglous, Theisen, and Vigil 1993, pp. 328) to large-scale MSW management facilities is generally less expensive than transporting the same amount of MSW in smaller vehicles. These efficiencies may occur because fewer vehicle drivers are required, and because doubling the volume of a container requires less than a doubling of the area of the sides of the container, conserving on container materials and fuel. ${ }^{31}$

Informal sector recycling enterprises in developing countries are generally extremely labor-intensive, and hence do not experience economies of scale. Low-tech capital-intensive 
recycling facilities appear to experience weak economies of scale, and high-tech capitalintensive recycling facilities actually appear to experience diseconomies of scale (Kreith 1994, pp. 1.14-1.15).

Economies of scale appear to exist in high-technology incineration facilities. In the United States, for example, these economies arise partly because of the difficulty of siting and obtaining regulatory permits and of the high cost of air pollution control devices (see, for example, Bailey 1993a and 1993b). ${ }^{32}$ This conclusion is based on statistical analyses of the association between operating and maintenance costs (excluding collection costs) and plant capacity for mass burn facilities (that is, facilities that burn largely unprocessed MSW) that generate both steam and electricity and range in capacity from 90 to 1,100 metric tons per day. However, the economies of scale do not appear to extend to mass burn facilities that generate only electricity, which operate on an even larger scale (average capacity of 1,100 metric tons of MSW per day) (Kreith 1994b, pp. 1.13-1.20).

Finally, evidence for the United States also suggests that the average cost of operating sanitary landfills declines by about 70 percent as their capacity increases from 227 to 2,700 metric tons per day (DeLong 1994, p. 36). Recently imposed United States Environmental Protection Agency regulations for site preparation and management to prevent groundwater contamination appear to impose even higher fixed costs on MSW landfills, creating even greater regulation-driven economies of scale.

To conclude, the limited economies of scale available in collection of MSW, and the greater economies of scale associated with transfer stations (see the preceding section), 
landfills, and other MSW management facilities suggest that collection services are best provided on a decentralized basis, while it may be more cost-effective for disposal and treatment facilities to be consolidated at a regional or metropolitan area level (Bartone and Bernstein 1993, pp. 49-50).

\section{Nonpecuniary Costs and Benefits of MSW Management Options}

Rational societal decisionmaking about alternative options for the management of MSW must account for the implications of those options for public health and environmental quality. Poor MSW collection or disposal practices can attract and promote the breeding of undesirable and potentially disease-transmitting or disease-causing insects, rodents, and pathogens, in particular, several of the diseases in the tropical cluster: schistosomiasis, South American trypanosomiasis, and Bancroftian filariasis. The World Bank estimates the burden to developing countries from these diseases alone was 8 million disability-adjusted life years in 1990 , or about 2 per 1,000 population, an estimated 25 percent of which could potentially have been averted through "feasible interventions" (World Bank 1993, pp. 90, 216-19), such as covering the MSW delivered to a dumpsite with fifteen to thirty centimeters of soil at the end of each day ${ }^{33,34}$ In addition to the modest direct contribution of MSW to the burden of disease in developing countries, inadequate management of MSW may also promote disease by causing open drains to become clogged, creating, for example, breeding grounds for mosquitos that can transmit malaria (Mensah and Whitney 1991, p. 163) and dengue, or leading to flooding in rainy seasons, which may increase human contact with any pathogen- 
infected feces contained in the MSW. ${ }^{35}$

Cleaning up MSW landfills contaminated by hazardous waste appears to be substantially more costly than placing the waste in specially designed hazardous waste landfills. In this regard, the experience of the United States is instructive. Closed MSW landfills in the United States comprise a large share of hazardous waste sites that have been targeted for cleanup under the 1980 Comprehensive Environmental Response, Compensation and Liability Act, also known as Superfund (U.S. Congress 1989, pp. 284-289). ${ }^{36}$ There are two major methods for cleaning up soil contaminated by hazardous wastes (which may include not only the remnants of waste deposited on the site in the past but also large amounts of neighboring soil that soaked up leachate from the waste) after it is excavated. One is to deposit the soil in licensed hazardous waste landfills, which have double plastic linings, high-tech leachate collection systems, and rigorous management, and which in the United States charge tipping fees of between US\$220 and US\$550 per metric ton of contaminated soil (Schneider 1994, p. A18). The other method is to incinerate the soil in special kilns at high temperatures (Bowen and Lambe 1994, p. 70), also at high cost.

A simple calculation suggests that placing hazardous waste into hazardous waste landfills instead of allowing it to contaminate ordinary MSW landfills is highly costbeneficial. For example, consider a landfill with a fifteen year capacity given the pace at which it is accepting MSW. Suppose ten percent of the waste disposed of at the dump is hazardous. Suppose further that shortly after the landfill reaches its capacity it is deemed necessary for public safety to excavate the entire dump site and place the wastes into a 
landfill specifically designed for hazardous materials. Assuming the disposal cost at the hazardous waste landfill is seven times (on a per ton basis) the cost at the MSW landfill (as evidence for the United States suggests, since the average MSW landfill disposal fee in the United States was US\$31 per metric ton in 1993 according to Bailey 1993a), this MSW management option would have a positive net present value only if the discount rate were in excess of 28 percent, which is far above even upper-bound estimates of the social discount rate. If the cleanup of the MSW landfill were instead deferred for another ten years, the break-even discount rate would be about 14 percent. The true break-even discount rate may be even higher, because the costs of excavating and transporting the waste from the MSW landfill to the hazardous waste landfill were not included in the calculation, and because the percentage of waste deposited in MSW landfills that is hazardous is likely to be less than ten percent. ${ }^{37}$ To the extent that more than just the waste deposited in the landfill must be excavated, due, for example, to the contamination of neighboring soil by toxic leachate, the break-even discount rate would be higher still.

Landfills may also contribute to the accumulation of greenhouse gases in the atmosphere. The Intergovernmental Panel on Climate Change estimated that between 20 and 70 million metric tons of methane are emitted annually by the anaerobic decomposition of organic waste, including MSW, at landfills worldwide, about 6 percent of estimated global annual methane emissions (U.S. Department of Energy 1993, p. 5). Developing countries, however, contribute relatively little to global MSW-related methane emissions, because their MSW is generally not deposited in sanitary landfills with daily cover that restricts access to 
oxygen and thereby promotes methane-producing anaerobic decomposition. A widespread shift toward sanitary landfill practices in developing countries may lead to an increase in methane emissions, but the contribution to the accumulation of greenhouse gases could be reduced if the methane were collected and flared or used as fuel, as recent developments in the United States confirm. ${ }^{38}$

Incineration of MSW releases several pollutants into the atmosphere, including particulate matter and incomplete combustion products, such as carbon monoxide, nitrogen oxides, chlorinated hydrocarbons, other hydrocarbons, acid gases, and metals (mercury and lead) (U.S. Congress 1989, p. 226). Modern incinerators in industrial countries generally use a combination of high furnace temperatures $(1,800$ degrees Fahrenheit) for complete combustion, electrostatic precipitators or baghouses (fabric filters) to remove particulate matter and metals, and scrubbers to remove acid gases. These measures eliminate most of the air pollutants associated with MSW incineration, though considerable controversy remains about the risks of air emissions to human and ecosystem health, often making the siting of new facilities difficult (U.S. Congress 1989, pp. 222-247). In many developing countries, MSW is burned with few or no emission controls, and therefore is likely to pose a greater threat to the environment per ton incinerated than it would if burned in a state-of-the-art incinerator. Nevertheless, use of coal, wood, or dried animal dung as fuel for household heating and indoor cooking and rapidly increasing vehicular emissions (usually without pollution controls) and industrial pollution are together far more important sources of morbidity and mortality than smoke from MSW landfills, although perhaps not for MSW 
landfill workers and scavengers and residents of nearby communities. ${ }^{39}$

The valuation of changes in health and environmental quality are classic economic problems, typically addressed by attempting to estimate (either through surveys or through more indirect means) individuals' willingness to pay for the benefits (or relief from the costs) of the relevant environmental or aesthetic effects. Even this method may provide only a lower bound valuation, because it does not take into account the preferences of future generations or individuals outside the local community who may have an interest in these issues. An example of how economists use indirect methods to value environmental quality can be found in Nelson, Genereux, and Genereux (1992). Using data on prices and other characteristics of houses located near a MSW landfill in the United States, this study estimated that other factors held constant, housing values rise with distance from a landfill (an average of 6.2 percent per mile within a two-mile radius of the landfill), presumably because the environmental and aesthetic problems of living near a landfill diminish as one locates further away from it. ${ }^{40}$

Economists also use contingent valuation surveys to estimate individuals' willingness to pay for improvements in their environment, although the use of this technique in the context of MSW management is still in its infancy. Contingent valuation surveys describe a program and its likely environmental consequences, for example, establishing an enhanced MSW collection and street cleaning program, and then ask questions designed to elicit truthful and consistent information on respondents' willingness to pay for the program. Surveys must be carefully designed and administered to ensure that respondents fully 
understand the scenario that is posed to them, which can often be very technical, that they do not try to behave strategically (that is, provide answers they believe may influence policy decisions rather than answers that reflect their valuation of the good in question), and that their answers focus on the question at hand and not on broader environmental issues. ${ }^{41}$ Households in developing country cities generally report little willingness to pay for improved MSW services, either because they place little value on improved MSW management or because they do not believe that hypothetical levels of service will be achieved. ${ }^{42}$

\section{Selected Economic Issues}

The generation, physical characteristics, and management of MSW is influenced by household income and by a variety of price variables. For a number of reasons, however, private economic behavior is unlikely to yield socially optimal outcomes with respect to MSW generation and management. Government intervention, which can take a variety of forms, may help overcome these market failures.

\section{A. The Role of Private Economic Behavior}

Both the cross-country and time-series regression results in tables 1 and 3 indicate that the generation of MSW is positively related to average income. Presumably, this result captures the net effect of several underlying mechanisms, including the effects of income on consumption, on the distribution of consumption between goods and services, and on the 
demand for environmental quality. Environmental quality is plausibly like most goods, in that high-income households are likely to demand more of it than low-income households (that is, they are willing to pay more for the same level of environmental quality, all else being equal). In addition, the complexity and distance (in time or space) of the health and aesthetic implications of low quality air, land, and water make it likely that better educated households have stronger preferences for environmental quality, thereby reinforcing the pure income effect on the demand for environmental quality (Baumol and Oates 1988, pp. 241-42).

The positive association between income and MSW generation may also embody the net impact of higher wages, which generally signify a higher value of time, on the MSW intensity of household activities. Higher wages are normally associated with greater purchases of prepared foods, which generate more packaging waste and less food scrap waste; with less use of ash-generating coal or wood for home heating and cooking and more reliance on electricity or methane, which require little effort to use and which generate no ash; and with less effort devoted to recycling MSW for personal pecuniary gain. Thus, higher wages affect not only the quantity of MSW that is generated, but also its composition and the degree to which households process it before discarding the residue.

A number of price variables also influence behaviors that affect the generation, composition, and management of MSW. All else being equal, higher market prices for recyclables provide incentives for households and firms to gather, clean, and transport materials extracted from MSW for sale and reuse. The prices that must be paid for the 
disposal of MSW also affect the actions of households and firms. ${ }^{43}$ For example, the least costly option for MSW disposal in developing countries -- dumping it in public spaces or burning it openly -- is also the most commonly chosen option (Bartone and Bernstein 1993, pp. 43-4). Although privately inexpensive, both in terms of out-of-pocket costs as well as environmental impacts, these practices may impose large costs upon society because of ensuing aesthetic, environmental, and health problems, especially in densely populated urban areas. The water supply contamination caused by dumping MSW in unlined and unsealed pits and the air pollution produced by burning MSW at dump sites or in crude incinerators may also cause urgent health and cleanup problems, particularly if the MSW contains hazardous materials. Individual households are unlikely to choose a more costly but less socially damaging way to dispose of their MSW unless they are reimbursed for their efforts, but collecting voluntary payments from the other households that benefit from such actions is fraught with difficulties, because private regulation of the use of common property resources is often difficult to monitor and enforce. Moreover, even if the market for MSW management services were able to achieve outcomes that reflected the willingness to pay for environmental quality of persons living today, it would still not reflect the preferences and willingness to pay of future generations, which will be forced to bear the costs of current MSW management practices. Households and firms left to their own devices may reap benefits from avoiding investment in environmentally protective MSW disposal modes, but leave a legacy of far greater harm to future generations. In other words, in evaluating the net present value of a project that would reduce future environmental damage, current 
generations may in effect use a discount rate that is too high, and hence gives too small a weight to the unexpressed concerns of future generations.

\section{B. The Role of Government}

Common property resources and intergenerational externalities will provide households and firms with incentives to underconsume services in the private market for MSW management. Because the benefits to households and firms of particular methods of MSW management fall short of the benefits to society, government intervention may enhance social welfare. In general terms, appropriate government interventions are those that align as closely as possible the private and social incentives for MSW disposal. This may be accomplished using a number of policy instruments. ${ }^{44}$

To begin, the government may undertake one or more of the tasks of MSW collection, transport, processing, and disposal, charging either a benefit tax (that is, a flat amount per household) or a volumetric tariff (that is, a curbside charge per unit volume of waste handled), with the latter mechanism providing an incentive for reduction of residual waste (Project 88 - Round II 1991, pp. 49-53), which can be achieved through production and consumption decisions and recycling activities, as well as by illicit dumping or burning of waste. In an analysis of per unit charges for curbside collection of MSW, Repetto and others (1992) estimated that environmental damage and the amount of MSW households set out for collection would be substantially reduced if households were charged a fee that fully reflected the costs of collection and disposal. ${ }^{45}$ Fullerton and Kinnamon (1993) present a 
theoretical model that suggests that if illicit burning or dumping are options for MSW disposal, and if the environmental damage from illicit burning and dumping of MSW is greater than the environmental damage from sanitary landfilling or incineration, then a deposit-refund scheme may be a more efficient policy than levying curbside charges. The clear advantage of a deposit-refund scheme, in which households and firms pay a fee when they buy certain goods, which is refunded when the MSW associated with the goods is disposed of in an acceptable manner (recycled), is that it provides households and firms with an incentive not to illegally dump or burn MSW. Moreover, it may be cheaper to manage a deposit-refund scheme than to monitor the disposal behavior of many small-scale illegal dumpers (Project 88 - Round II 1991, p. 62). ${ }^{46}$ Nevertheless, a flat benefit tax charged to all households as part of their utility or property tax bills may be the most effective way for cities in developing countries to pay for MSW management, reduce the incentive to illegally dump MSW, and to subsidize MSW management services for poor neighborhoods; such an arrangement has financed 100 percent of the cost of MSW management in Santiago, Chile (Bartone and others 1991, p. 504). ${ }^{47}$

Incentive policies that indirectly affect prices are also an option. Fees can be imposed on goods at the retail level based on the expected cost of disposing of the product. This policy is less precise than curbside charges, because it does not directly influence MSW disposal decisions; however, it may affect consumption decisions, and hence the composition of MSW. Nevertheless, if a system of curbside charges is too costly to operate, as would probably be the case in developing countries, packaging taxes may be a second-best policy 
(Project 88 - Round II 1991, p. 53).

A related policy would be to tax the virgin materials content of goods at the point of production to reflect their disposal costs. This may be easier to administer than retail charges, and would give producers, and ultimately consumers, a clear incentive to favor recycled materials over virgin materials. A problem with this policy relates to its imposition on producers, because variations in disposal costs within the product's geographic market suggest that the tax will not reflect local disposal costs accurately (Project 88 - Round II 1991, p. 54). Another issue is the distributional impact of retail or virgin content disposal charges. Some evidence, at least for the United States, indicates that low-income households are more apt to purchase smaller size packaged goods than to buy in bulk, perhaps because they cannot afford storage space or to tie up their limited funds in stored food. Thus, lowincome households may purchase more packaging per unit of product than high-income households, which suggests that a virgin materials tax would be regressive (Rathje and Murphy 1992, pp. 66-67). Policymakers can create incentives that indirectly affect MSW disposal behavior. For example, a problem policymakers in industrial countries frequently face is local resistance to the siting of MSW disposal facilities. So-called NIMBY (not in my back yard) activism may arise in developing countries even if government authorities are trying to site and construct environmentally friendly facilities. One reason NIMBY may become an issue in developing countries is that previous MSW landfills were almost universally so poorly managed that many governments have little credibility when claiming that the new facilities will be well managed. A solution may be to require a locality to hold 
a binding referendum if the government or a firm proposes to build an MSW disposal facility within its borders. This would give the builders of the facility incentives to pick communities whose voters would be willing to accept the smallest compensation package, that is, those communities either least affected by the facility or most in need of the compensation (Project 88 - Round II 1991, pp. 65-67).

Another government policy would be to educate households about the health and aesthetic implications of undesirable MSW management practices (Bartone and Bernstein 1993, pp. 51-2; Ohnesorgen 1993, p. 10). For example, in the United States in the early 1900 s, youth leagues were set up in many cities to educate the population about proper handling and disposal of MSW (Melosi 1981). More sophisticated approaches to mass education can be adopted using radio and television and in schools.

There may be underinvestment in the research and development of socially efficient MSW management practices. In particular, entrepreneurs generally do not have an incentive to develop small-scale, labor-intensive methods that may be most appropriate for developing countries, because it is difficult to appropriate much of the gains from methods that are easy to imitate and inexpensive to implement. Governments can correct this problem by supporting research into the development of low-cost MSW management techniques or institutional arrangements for handling MSW in environmentally friendly ways.

Well-intentioned government policies that influence prices may have unintended and undesirable consequences on the quality and scope of MSW management. For example, in India, Indonesia, and other developing countries, governments subsidize the production of 
chemical fertilizers, which may stifle the development of agricultural markets for compost. Ironically, compost can help conserve on fertilizer use and reduce runoff pollution by enhancing the ability of soil to prevent fertilizer from leaching out after rainfall.

\section{The Role of Private Provision of MSW Management Services}

Government contracting of MSW management services on a competitive basis may be more efficient than noncompetitive government provision. Profit-seeking firms generally have both greater flexibility and incentives than government bureaucracies to redeploy workers and physical capital quickly in response to changing circumstances and to design and implement cost-cutting innovations. The key to efficient privatization of MSW management is fostering competition among prospective providers. The government's ability to promote competitive bidding by private firms (and even by public agencies) and realize the potential gains in efficiency depends on the degree to which government can hold contractors accountable for their performance. The better able the government is to specify the tasks it seeks to accomplish, including setting standards for environmentally sound practices, the more easily it can evaluate contractor performance. Furthermore, the more effective the government is at implementing a mechanism for penalizing poor performance, the greater the likelihood that private provision of MSW management services will be more efficient than public provision (Donahue 1989, pp. 79-80).

By contrast, a private firm granted exclusive control over a city's MSW management without sufficient monitoring of its performance by the city government may exercise its 
monopoly power by charging such high prices that it earns a rate of return on its investment above what could be earned on the next best alternative investment. By failing to foster an environment that is conducive to competition, a city government may find that privatization does not increase the efficiency of MSW management, and may lead to rent-seeking behavior, in which the lure of excess profits or above-market wages encourages entrepreneurs and labor unions to influence governments (through lobbying, campaign contributions, bribes, kickbacks, etc.) to make MSW spending decisions that may be inefficient (Donahue 1989, p. 53). For example, the threat of a strike by public MSW collection workers can be a particularly potent weapon, because the suspension of MSW collection service can be quite unpleasant, leading voters to put extreme pressure on elected officials to settle labor disputes (Donahue 1989, p. 67).

A number of empirical studies have focussed on the social efficiency of private provision of MSW collection services in Canada, the United Kingdom, and the United States. These studies generally find that noncompetitive public provision of MSW collection services is less efficient than competitive contracting by private firms, although some of the studies found that open competition, that is, allowing free entry and exit of firms into the regulated MSW collection market, was the least efficient of the three modes of service delivery. Moreover, some evidence suggests that public agencies that bid against private firms for MSW collection contracts appear to be about as efficient as their competitors, which indicates that the efficiency gains from competition do not depend on the form of ownership of the provider of the MSW collection service (Donahue 1989, pp. 60-68). A review of 
private sector provision of MSW services in Latin America suggests that privatizing MSW collection is efficient, partly because of effective government regulation and monitoring of private collection firms. Unfortunately, private and municipal collection enterprises at times do not dispose of all MSW at the nearly state-of-the-art, capital-intensive sanitary landfills in Santiago, Caracas, and Buenos Aires and instead dump some MSW at open landfills. This is apparently because the local MSW management agencies have had trouble collecting sufficient fees to pay for tipping charges at the sanitary landfills (Bartone and others 1991). A solution to this problem may be to subsidize tipping fees at the sanitary landfills to reduce the incentive for illegal and unsafe dumping.

\section{Case Studies in MSW Management}

The purpose of this section is to provide brief descriptions of MSW management experiences in the United States and in several locations in developing countries. These case studies illustrate the wide range of private and public factors that influence decisions on MSW management, the variety of approaches adopted to address those factors, and the quality of the outcomes.

\section{A. United States}

Expenditures on MSW collection and disposal in the United States increased from US $\$ 4.7$ billion in 1972 to US $\$ 14.5$ billion in 1992 (both figures in 1987 U.S. dollars), that

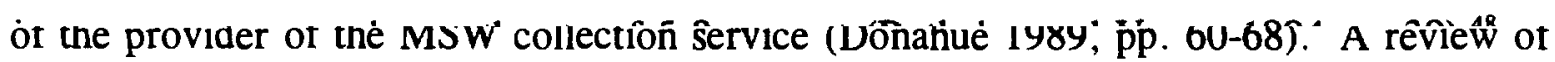


Although expenditures in 1992 amounted to only 0.29 percent of GDP that year (up from 0.15 percent in 1972), their rate of increase during 1972-92 substantially exceeded the average annual rates of increase of real GDP per capita (1.4 percent) and population (1.0 percent). Given the estimated elasticities of MSW generation with respect to population and income reported in table 3, this expenditure increase suggests a sharp rise in the real per ton cost of managing MSW. In addition, the increase in MSW expenditures coincided with growing employment in the MSW management sector, an increasing share of which is private. $^{49}$

The doubling of real per capita MSW collection, transport, and disposal costs in the United States during the past two decades partly reflects a nearly one-third increase in daily per capita waste generation, up from 1.5 kilograms in 1970 to about 2.0 kilograms in 1990 (U.S. EPA 1992, p. 5-2). It also reflects the increasingly stringent regulations imposed by states and, more recently, by the federal government, that require landfill operators to adhere to stricter regulations on daily cover of MSW and leachate and methane collection and treatment. ${ }^{50}$ New landfills are becoming significantly more difficult to site because of local resistance, causing increasing amounts of MSW to be hauled further, adding to the cost.

About 66 percent of MSW is currently landfilled, roughly the same share as in 1965 (U.S. EPA 1992, pp. 3-2, 3-3). Nearly fifteen percent of MSW generated in the United States is recovered for recycling, up from 6.6 percent in 1965 and 9.9 percent in 1985 , with much of the increase since 1985 due to the imposition of mandatory recycling goals or programs by many states. Judging whether recycling programs are cost-beneficial is 
hampered by poor, incomplete, or inconsistent data (see, for example, Spencer 1994). ${ }^{51}$ Another 2.1 percent of MSW is composted, for a total of 17.0 percent of MSW generation that is recovered before disposal. Of total MSW generated, 15.2 percent is incinerated to generate energy, up sharply from 4.6 percent in 1985 and close to zero in the 1970 s. Only 1.1 percent of MSW is incinerated without energy recovery, which represents a steep decline from 25.9 percent in 1965 . The rise of recycling and composting and of the conversion of waste to energy reflects increased awareness of the potential value that resides in MSW, more ambitious state recycling goals, and possibly increased value.

The sharp rise in the percentage of MSW being burned for energy recovery (U.S. EPA 1992 , pp. 3-2 - 3-3) from 1985 to 1990 was due to a combination of factors, including growing concerns that landfill capacity was inadequate, regulations requiring utilities to purchase electricity from incinerators at premium rates, investment tax credits covering the construction of incinerators, and inexpensive government-backed financing for the construction of incinerators. Most of the incentives for incinerator construction were reduced or discontinued by the early 1990s and MSW incineration fees are now roughly double the corresponding landfill fees (Bailey 1993b), moderating the growth in their use. Moreover, landfill capacity has increased considerably in the past several years, leading to reduced disposal prices per ton (Bailey 1992).

\section{B. Locations in Developing Countries}

Although the experience of the United States illustrates some key influences on MSW 
management, the developing country context is different in many respects and quite diverse. Notwithstanding this diversity, a number of generalizations emerge from a brief review of MSW management experiences in a sample of developing country locations: Bangkok, Dar es Salaam, Jakarta, Mexico City, Shanghai, and Taiwan. These are discussed below.

(1) MSW is a sizable problem throughout the developing world. Moreover, it is a growing problem, partly because of population growth, but also because of rising per capita incomes in much of the developing world, which have led to rising per capita MSW generation.

Shanghai's per capita MSW generation rate of 0.80 kilograms per person per day translates into 2.50 million metric tons per year, up from 1.31 million metric tons at the beginning of the 1980s (Ward and $\mathrm{Li}$ 1993, p. 31). From 1982 to 1989 daily per capita solid waste generation in Bangkok increased from 0.6 to 0.9 kilograms (Muttamara, Visvanathan, and Alwis 1992/93, p. 7). In Taiwan, per capita MSW increased an average of 4.8 percent per year from 1980 to 1991 (Republic of China 1992, pp. 160-61). Mexico City residents generate about 1.0 kilogram of MSW per person per day, double the estimated rate in the 1950s, with even faster growth in per capita generation of nonbiodegradable waste (Meade 1992, p. 150).

The character of the MSW problem also differs from one location to another, depending on the physical characteristics of MSW and local geography. Coal, which generates substantial amounts of ash, is still widely used to heat homes in Shanghai (although ash as a percentage of the MSW waste stream has been decreasing since the mid-1980s). 
Moreover, per capita MSW generation rates are nearly 50 percent higher in the summer because of a seasonal increase in food wastes from fruits and vegetables (Ward and Li 1993, pp. 31-32). As in Shanghai, narrow streets make the collecting of waste relatively difficult in Bangkok.

(2) Accelerating urbanization has increased the burden on municipal governments of providing universal and efficient MSW collection services.

The proportion of the population of developing countries that lives in urban areas increased from 25 to 46 percent between 1970 and 1991. Moreover, the growth rate of urban populations in developing countries has accelerated from an annual average growth rate of 3.7 percent in the 1970 s to 6.3 percent in the $1980 \mathrm{~s}$, even though the (much lower) overall annual average rate of population growth for developing countries decelerated from 2.2 percent in the 1970s to 2.0 percent in the 1980s (The World Bank 1993, pp. 289 and 299). This trend, combined with rising per capita incomes in many developing countries, has led to burgeoning concentrations of MSW in metropolitan areas. As we noted in section II.B., it is likely that these trends drive up the average cost per ton of MSW collection, processing, and disposal and strain the MSW management capacities of many city governments.

The Jakarta city government and some private companies collect only about 60 to 80 percent of MSW and transport it to open, unlined dumps on the outskirts of the city, where some of it is burned. Much of the remainder is burned in the open air within the city, 
dumped in local waterways, or left to decompose on unused plots of land. In Shanghai, MSW is collected in a labor-intensive manner and is then transported to landfills by truck and barge. In the process, much MSW is spilt into waterways and scattered along streets as only 60 percent of the trucks hauling MSW are covered (Ward and Li 1993, pp. 31-32). As in Jakarta, a substantial portion of MSW in the city of Bangkok (about 20 percent) is believed to be dumped into the city's canals or burned (Muttamara, Visvanathan, and Alwis $1992 / 93$, p. 7). In 1988 , Dar es Salaam's population of roughly 1.5 million people generated an estimated 1,040 to 1,340 tons of MSW per day. The city's system for handling MSW involves collection and transport by truck to an open dump site about six kilometers outside the city, but the scope and effectiveness of this system are limited. Only about 180 tons of MSW are actually collected each day by the city's fleet of thirty tipper trucks operating on a limited number of accessible streets. MSW collection in Mexico City is accomplished by 2,000 collection trucks (including street sweepers), only 60 to 65 percent of which are typically in operating condition at any point in time (Meade 1992, p. 151).

(3) MSW processing and disposal practices are frequently poor, which has serious adverse effects on the quality of air, water, and land.

Shanghai's landfills, most of which rest on land with sandy soils and high water tables, cause foul odors, insect concentrations, and leachate pollution of local drinking water that adversely affect many people (Ward and Li 1993, pp. 37-40). In 1984 the Shanghai 
government built a simple MSW composting plant with a capacity of 300 metric tons per day, in which MSW is composted in large, closed containers for one month and then put on grates and sorted by particle size. However, due to poor quality control, the city's MSWderived compost is heavily contaminated with glass, plastics, and metals, and therefore of relatively little value to local farmers (Ward and Li 1993, p. 33). Similarly, in Bangkok, 90 percent of collected MSW is disposed of by open dumping, with the remaining 10 percent composted or incinerated (Muttamara, Visvanathan, and Alwis 1992/93, p. 10). Most of Dar es Salaam's household waste is discarded into open pits near households, on streets, in markets, or in stormwater drainage channels (Yhdego 1991, p. 261). Some of the MSW is burned. Moreover, the city's main dump, which was fairly isolated when it was established in 1965 , is now close to several communities and contributes leachate to the nearby Luhanga River (Yhdego 1988, p. 178).

(4) Much informal sector recycling is taking place.

Bangkok households typically separate newspapers, magazines, cardboard, and bottles from their MSW and sell these items to door-to-door collectors. Street scavengers pick through waste in streetside containers, collection crews spend an estimated 40 percent of their time sorting through the MSW for recyclable materials they can sell to supplement their incomes, and scavengers pick over the remaining MSW at the dumps. Scavengers and refuse collectors sell recyclables to small-scale recycling shops near the dumps (Muttamara, Visvanathan, and Alwis 1992/93, p. 8). In Mexico City, collection workers sort through the 
MSW for recyclables they can sell to supplement their incomes. However, this has become increasingly difficult, because the quantity and value of recyclable materials in the waste given for collection declined dramatically following the economic crisis that began in 1982 , when household help began to screen the waste more carefully (Meade 1992, p. 152). In Dar es Salaam, considerable scavenging, under very difficult conditions, takes place at both the main dump and throughout the city (Yhdego 1991, p. 263). Some organized extraction of recyclables from MSW takes place at Shanghai's landfills (Ward and Li 1993, p. 36). Considerable MSW recycling also occurs in Jakarta. Throughout the city an estimated 30,000 to 60,000 scavengers extract recyclable materials such as glass, paper, cardboard, metals, wood, rubber, bones, and textiles from the waste stream. They sell these materials to small-scale entrepreneurs who sort, clean, bundle, and sell the materials to other middlemen who specialize in particular materials, which they in turn transport and sell to recycling factories.

\section{Conclusion}

In 1992 the Gallup International Institute conducted an in-depth international survey of attitudes toward environmental quality. The survey polled large, representative samples of citizens of twenty-four countries (twelve industrial and twelve developing countries, accounting for about 40 percent of global population) in Eastern and Western Europe, North America, Latin America, Asia, and Africa, giving it the broadest coverage of regions and economies of any international survey on the environment to date (Dunlap, Gallup, and 
Gallup 1993b, p. 8).

Two of the survey questions made specific reference to MSW generation and management. One question asked whether people who "use more resources than they need" and who "throw away too much" contribute a "great deal" to their nation's environmental problems. Affirmative response rates among the twenty-four countries ranged from about one-third to two-thirds of their respective populations (Dunlap, Gallup, and Gallup 1993a, figure $7 \mathrm{~d}$ ) and 54 percent on a population-weighted basis. The most interesting aspect of this survey question is that the affirmative response rates do not vary systematically with per capita income.

Another question asked whether "inadequate sewage, sanitation and garbage disposal" was a "very serious" problem (Dunlap, Gallup, and Gallup 1993, figure 9c). The range of affirmative response rates was wider than for the other question, between 2 and 62 percent, although the population-weighted affirmative response rate was only 37 percent. Notably, a strong negative relationship was apparent between concern about this problem and income. ${ }^{52}$

The Gallup poll findings suggest that concern about MSW generation is strong in both developing as well as industrial countries, reflecting the fact that the burden of MSW is large and growing rapidly, especially in developing countries. Between 1990 and 2010, we project a 2.7 percent annual rate of increase in MSW generation in the developing counties, nearly double the projected rate of increase for the industrial countries. The Gallup poll findings also suggest that the capacity of MSW management systems is weak in many developing countries. Nevertheless, there are encouraging signs that economic development leads to 
stronger institutional structures and a willingness to experiment and invest in projects that can alleviate long-standing MSW problems in ways that are appropriate to a country's level of development.

For low-income countries, the most appropriate way to strengthen MSW management may be to remove sanctions on informal sector collection and recycling enterprises, integrate them with other MSW management strategies, and explore ways that these enterprises can economically divert more MSW from landfills (Bartone and Bernstein 1993, pp. 50-51) or diversify into the provision of MSW collection services. As one example, even though scavengers appear to extract most of the readily recyclable material from Jakarta's MSW, interest has grown in the possibility of extracting further value from the organic portion of the remainder of the MSW by converting it into compost. In recent years, investigators have conducted a number of projects to explore the technical and economic viability of composting the biodegradable portion of nonrecycled MSW. Perhaps the most promising of these is a project sponsored by the government of Indonesia that began by establishing an experimental station in Jakarta in late 1989 to (a) develop a composting technique appropriate for the city's waste stream, climate, and labor-surplus economy; (b) study the cost of producing compost using that technique; and (c) investigate the economic uses of compost and the nature and potential size of the compost market. By late 1990, the investigators had developed a technique for which preliminary technical and financial results were sufficiently encouraging to justify the establishment of four pilot projects. These projects, known as Enterprises for Recycling and Composting (ERCPs), were operated by private entrepreneurs (all former 
scavengers or small-scale recycling industry middlemen), and were supported by the government through the provision of partial start-up grants, technical assistance, worker training, and a guaranteed purchase arrangement for the compost produced. The government also supported the pilot projects by securing their access to suitable land and by arranging for the daily delivery of fresh MSW and the removal of noncompostable residuals and hazardous materials as they accumulated. In addition, the government supported experimental analyses of the benefits of compost in Indonesian agriculture and aquaculture. Finally, the pilot projects served as a testing ground for solutions to problems of odor, flies, aesthetics, and community relations, all of which had to be addressed before a broader expansion of ERCPs into new city neighborhoods could proceed. As the pilot projects appear to demonstrate that high quality compost can be produced from Jakarta's MSW at a relatively low cost, a tenfold expansion of ERCPs is currently underway. However, given government subsidization of chemical fertilizer and uncertainties about the magnitude and price-sensitivity of the demand for compost, the long-term viability and expansion of ERCPs remains an open question.

In addition to coordinating official MSW management activities with those of the informal sector, local governments in lower-middle-income developing countries can contract with private firms for MSW collection financed by flat benefit taxes billed with property taxes or utility fees. The fees can also finance MSW management services and subsidize service for low-income neighborhoods, as is the case in several South American cities (see section III.B. above). Moreover, large metropolitan areas with sufficiently strong municipal 
governments can take advantage of economies of scale in the operation of transfer stations and landfills by setting up metropolitan area authorities to manage these facilities, an approach that several cities in Mexico are trying (Bartone 1991). For example, Mexico City recently closed seven open air, extremely polluted dumps, where at one time 2,500 scavengers lived and supported themselves (Oster 1989) and has replaced the dumps with ten waste transfer stations and two operating landfills that meet strict environmental standards, including clay linings to prevent seepage of leachate and 0.3 meters of daily soil cover on deposited MSW to contain odors and protect the MSW from runoff after a rain (Meade 1992, p. 151).

Upper-middle-income countries are unlikely to have a significant informal sector recycling industry and therefore may benefit from adopting pricing policies that encourage households to recycle their MSW. A deposit-refund program for polyethylene terephthalate plastic bottles was introduced in 1989 in Taiwan. Initial participation levels were low because of inadequate public information programs, inconvenient dropoff locations (Republic of China 1993, p. 254), and a low deposit per bottle of US\$0.02 per bottle (O'Connor 1993 , p. 38). But in 1992 Taiwan's Environmental Protection Agency strengthened the program by providing 13,500 collection bins in stores, opening up a toll-free telephone information line, and raising the deposit to US\$0.08 per bottle, an amount thought to correspond more closely to the social cost of inadequate disposal (Republic of China 1993, p. 254). By making recycling more convenient and increasing the deposit, the government increased the net private benefits of program participation (Republic of China 1993, p. 254), the result being a 
dramatic rise in participation levels and presumably social welfare as well..$^{53}$ Upper-middleincome countries also may benefit from the same privatization and regionalization policies suggested for middle-income developing countries.

Expanding MSW generation represents an increasingly serious challenge to environmental quality and public health around the world. Although transplanting MSW management practices from one country to other very different countries generally does not work, international experience nonetheless offers many valuable lessons in the design and implementation of cost-beneficial systems for confronting this challenge. Rising income levels in rapidly developing countries appear not only to increase MSW generation, but also to stimulate improved MSW management. 
Table 1

Ordinary Least Squares Estimates of the Covariates of MSW Generation Rates :

Dependent Variable: Natural Logarithm of Annual MSW Generation by Weight

\begin{tabular}{|c|c|c|c|c|c|c|}
\hline & \multicolumn{2}{|c|}{ Country cross-section } & \multicolumn{2}{|c|}{ China, 1990} & \multicolumn{2}{|c|}{ United States, 1992} \\
\hline & Unrestricted & Restricted & Unrestricted & Restricted & Unrestricted & Restricted \\
\hline $\begin{array}{l}\text { Log gross } \\
\text { domestic product } \\
\text { per capita }\end{array}$ & $\begin{array}{c}0.34 \\
(0.06)\end{array}$ & $\begin{array}{c}0.34 \\
(0.06)\end{array}$ & $\begin{array}{c}0.26 \\
(0.13)\end{array}$ & $\begin{array}{c}0.29 \\
(0.12)\end{array}$ & $\begin{array}{l}0.62 \\
(0.23)\end{array}$ & $\begin{array}{c}0.60 \\
(0.23)\end{array}$ \\
\hline Log population & $\begin{array}{c}1.04 \\
(0.04) \\
\end{array}$ & $\begin{array}{l}1.00 \\
(--)\end{array}$ & $\begin{array}{c}0.95 \\
(0.06) \\
\end{array}$ & $\begin{array}{l}1.00 \\
(--1)\end{array}$ & $\begin{array}{c}0.96 \\
(0.04) \\
\end{array}$ & $\begin{array}{l}1.00 \\
(--)\end{array}$ \\
\hline R-squared & 0.96 & 0.96 & 0.87 & 0.87 & 0.94 & 0.94 \\
\hline $\begin{array}{l}\text { Number of } \\
\text { observations }\end{array}$ & 36 & 36 & 45 & 45 & 33 & 33 \\
\hline
\end{tabular}

$(--)=$ not applicable.

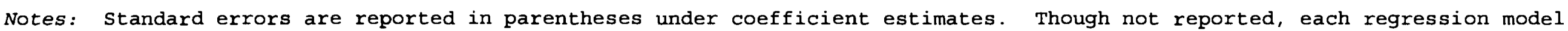
was specified with a constant term.

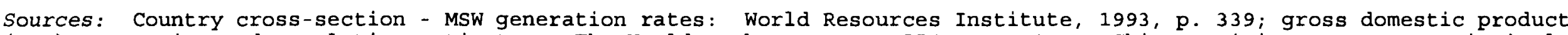

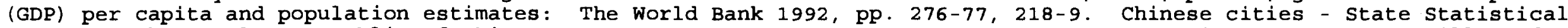

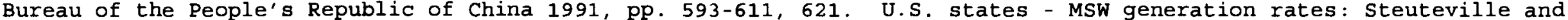

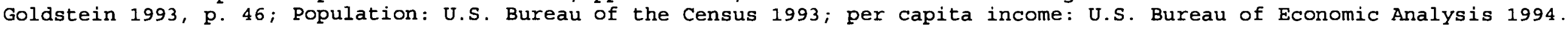


Table 2

Estimated World MSW Generation and selected Characteristics by Income Classification of Economies, 1990

\begin{tabular}{|c|c|c|c|c|c|c|}
\hline \multirow[b]{2}{*}{$\begin{array}{c}\text { Economy income } \\
\text { group }\end{array}$} & \multicolumn{2}{|c|}{ Total MSW generation } & \multicolumn{2}{|c|}{ Population size } & \multirow[b]{2}{*}{$\begin{array}{l}\text { Percentage } \\
\text { of world } \\
\text { total GDP }\end{array}$} & \multirow[b]{2}{*}{$\begin{array}{l}\text { Kgs of MSW } \\
\text { per capita } \\
\text { per day }\end{array}$} \\
\hline & $\begin{array}{l}\text { Millions } \\
\text { of metric } \\
\text { tons/year }\end{array}$ & $\begin{array}{c}\text { Percentage } \\
\text { of world } \\
\text { total }\end{array}$ & $\begin{array}{l}\text { Millions } \\
\text { of people }\end{array}$ & $\begin{array}{l}\text { Percentage } \\
\text { of world } \\
\text { total }\end{array}$ & & \\
\hline Low & 598 & 46.3 & 3,091 & 58.5 & 18.7 & 0.53 \\
\hline Lower-middle & 145 & 11.2 & 629 & 11.9 & 9.9 & 0.63 \\
\hline Upper-middle & 193 & 14.9 & 748 & 14.2 & 16.5 & 0.71 \\
\hline High & 357 & 27.6 & 816 & 15.4 & 54.9 & 1.20 \\
\hline All Economies & 1,293 & 100.0 & 5,284 & 100.0 & 100.0 & 0.67 \\
\hline
\end{tabular}

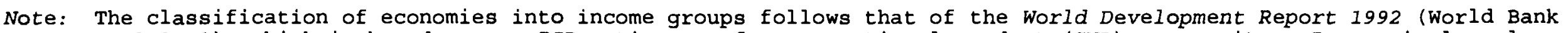

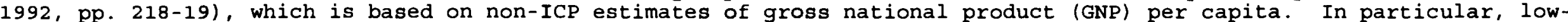

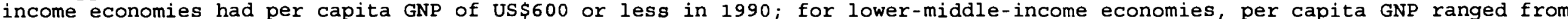

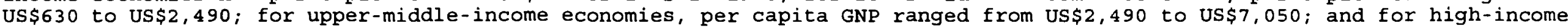
economies, per capita GNP was US\$9,550 or greater.

For methodology and sources used to construct this table, see endnotes 8-10. 
Table 3

Ordinary Least Squares Estimates of the Covariates of MSW Generation Rates: Time Series Data Sets Dependent Variable: Natural Logarithm of Annual MSW Generation by Weight

\begin{tabular}{|c|c|c|c|c|}
\hline & $\begin{array}{c}\text { Taiwan } \\
\text { (1980- } \\
91)\end{array}$ & $\begin{array}{c}\text { Taiwan } \\
(1980- \\
91) \\
\text { constrai } \\
\text { ned }\end{array}$ & $\begin{array}{c}\text { U.S. } \\
(1970-88)\end{array}$ & $\begin{array}{c}\text { U.S. (1970- } \\
88) \\
\text { constrained }\end{array}$ \\
\hline $\begin{array}{l}\text { Log gross domestic product } \\
\text { per capita }\end{array}$ & $\begin{array}{c}0.59 \\
(0.21) \\
\end{array}$ & $\begin{array}{c}0.72 \\
(0.04) \\
\end{array}$ & $\begin{array}{r}0.86 \\
(0.16) \\
\end{array}$ & $\begin{array}{c}0.63 \\
(0.05) \\
\end{array}$ \\
\hline Log population & $\begin{array}{r}1.63 \\
(1.02) \\
\end{array}$ & $\begin{array}{l}1.00 \\
(--)\end{array}$ & $\begin{array}{c}0.63 \\
(0.25)\end{array}$ & $\begin{array}{l}1.00 \\
(--)\end{array}$ \\
\hline R-squared & 0.98 & 0.97 & 0.98 & 0.92 \\
\hline Durbin-watson statistic & 1.73 & 1.90 & 1.61 & 1.69 \\
\hline Number of observations & 12 & 12 & 19 & 19 \\
\hline
\end{tabular}

$(--)=$ not applicable.

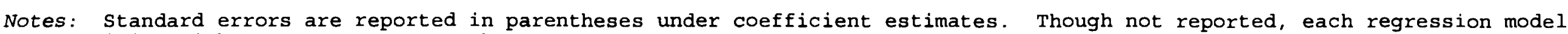

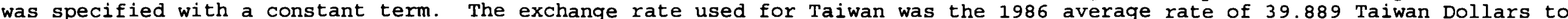
one U.S. Dollar (U.S. Bureau of the Census, 1993, p. 871).

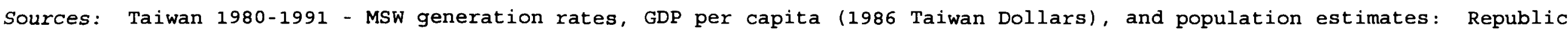

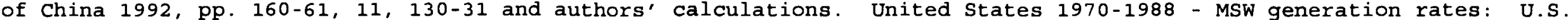

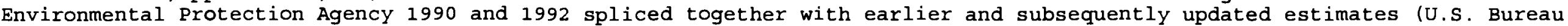

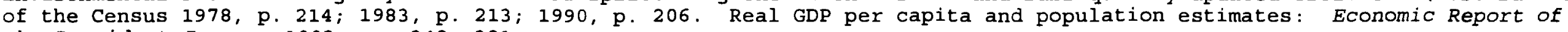
the President January 1993, pp. 348, 381. 
Table 4

Physical Characteristics of Municipal Solid Waste, Selected Locations and Years

\begin{tabular}{|c|c|c|c|c|c|}
\hline Category & $\begin{array}{c}\text { Bangkok }{ }^{1} \\
(1989)\end{array}$ & $\begin{array}{c}\text { Dar es } \\
\text { Salaam } \\
(1988)\end{array}$ & $\begin{array}{c}\text { Jakarta } \\
(1989)\end{array}$ & $\begin{array}{c}\text { Mexico } \\
\text { City } \\
(1980)\end{array}$ & $\begin{array}{l}\text { U.S. } \\
(1990)\end{array}$ \\
\hline $\begin{array}{l}\text { Discard rate (kilograms per capita } \\
\text { per day) }\end{array}$ & 0.9 & $0.7-0.9$ & 0.5 & 1.0 & 1.6 \\
\hline $\begin{array}{l}\text { Landfill density (kilograms per } \\
\text { cubic meter) }\end{array}$ & 615 & 980 & 1,000 & 640 & 460 \\
\hline $\begin{array}{l}\text { Potential landfill utilization rate } \\
\text { (cubic meters per capita per year) }\end{array}$ & 0.5 & 0.3 & 0.2 & 0.6 & 1.3 \\
\hline $\begin{array}{l}\text { Percentage biodegradable (by } \\
\text { weight) }{ }^{4}\end{array}$ & 67 & 69 & 62 & 66 & 67 \\
\hline $\begin{array}{l}\text { Moisture content of biodegradable } \\
\text { portion of MSW (percent) }\end{array}$ & 31 & 44 & 42 & 34 & 20 \\
\hline $\begin{array}{l}\mathrm{C} / \mathrm{N} \text { ratio of biodegradable portion } \\
\text { of } \mathrm{MSW}\end{array}$ & 88 & 32 & 24 & 49 & 90 \\
\hline $\begin{array}{l}\text { Energy content of MSW (kilojoules } \\
\text { per kilogram) }\end{array}$ & 11,300 & 6,300 & 6,000 & 8,900 & 12,900 \\
\hline \multicolumn{6}{|c|}{ Composition of MSW (percentage by weight) } \\
\hline Paper & 12.4 & 6.2 & 2 & 19.2 & 32.3 \\
\hline Food waste & 39.2 & 62.5 & 60 & 43.1 & 8.1 \\
\hline Textiles & 3.2 & 1.8 & -- & 5.7 & 3.3 \\
\hline Plastic & 9.4 & 0.3 & 2 & 5.0 & 9.8 \\
\hline Leather/rubber & 1.9 & & & $N / A$ & 2.7 \\
\hline Metals & 1.7 & 1.2 & 2 & 3.7 & 7.7 \\
\hline Glass & 3.2 & 0.3 & 2 & 8.4 & 6.5 \\
\hline Miscellaneous & 29.0 & 27.7 & 32 & $14.9^{6}$ & $29.6^{6}$ \\
\hline
\end{tabular}

N/A Not available. C/N Carbon to nitrogen. One kilojoule = 0.948 British Thermal Unit (BTU). 
Notes to Table 4

${ }^{1}$ Estimates are for residential MSW from low income housing areas.

${ }^{2}$ Daily per capita MSW generation rate is based on an estimated total daily MSW generation rate of 5,000 metric tons per day (Bennett and others 1992, p. 1) and estimated population of 9,882,000 in 1991 (The World Almanac 1993, p. 818).

${ }^{3}$ Landfill densities of MSW components are from U.S. Environmental Protection Agency 1992, p. 6-9. The landfill density estimates for each material were based on experimental compaction of each material to simulate landfill conditions in the United States. These densities were used to estimate landfill density of MSW in the LDC cities. Potential landfill utilization rates are based on the landfill densities of MSW components and are upper bound estimates because when the materials in MSW are intermingled there tends to be less void space than if only one material were landfilled.

"Percentage biodegradable is the sum of shares of paper, wood, yard wastes, and food wastes.

${ }^{5}$ Wood and grass constitute 15.2 percent of total MSW discards and are included under "miscellaneous" in the table but counted separately as yard waste to compute average physical characteristics of MSW.

${ }^{6}$ Yard wastes (that is, grass and shrub trimmings) constitute 4.1 percent and 26.3 percent of total MSW discards for Mexico City and the United States, respectively, and are included under "miscellaneous" in the table, but counted separately to compute average physical characteristics of MSW.

Sources: United States: U.S. Environmental Protection Agency (1992, p. 2-4). Bangkok: Muttamara, Visvanathan, and Alwis (1992/93, p. 14). Dar es Salaam: Yhdego (1991, p. 260). Jakarta: Yhdego (1991, p. 260). Mexico City: Rathje, Reilly, and Hughes (1985, p. 66). Moisture content and $\mathrm{C} / \mathrm{N}$ ratios of biodegradable MSW components and energy content are from Tchobanoglous, Theisen, and Vigil (1993, pp. 70, 689, 84). 


\section{Glossary of Technical Terms ${ }^{54}$}

Aerobic

composting

Anaerobic composting

Collection

Compost

Landfilling

Leachate
A method of composting organic wastes using bacteria and other organisms that require oxygen. This method requires that oxygen be diffused throughout the organic material, either by mixing the material to expose it to air or forcing air through perforated pipes that pass through the material.

A relatively slow method of composting organic wastes using bacteria that cannot function in the presence of oxygen. Methane, which can be used as a fuel, is an additional product of anaerobic composting.

Gathering MSW from where it is generated and transporting it to a transfer station, processing facility, or landfill to safeguard public health, limit congestion, and preclude unpleasant odors and aesthetically offensive scenes. The goal of disposal is to isolate and contain of the residual waste left after processing.

A soil amendment derived from the decomposition of organic wastes. It is valuable in agriculture, horticulture, and land reclamation because it improves the ability of soil to retain moisture and chemical fertilizers and to resist erosion. It can also be used as a feedstock in aquaculture and as intermediate cover in MSW landfills which both reduces the volume of wastes that needs to be landfilled and prevents MSW from blowing away into residential neighborhoods or attracting pests.

Disposal of MSW by burying it.

Liquid that has seeped through MSW in a landfill and has accumulated dissolved or suspended materials that may render it harmful. 
Table 5

\section{Glossary of Technical Terms ${ }^{54}$}

Low-tech capitalintensive recycling facility

High-tech capitalintensive recycling facility

Municipal solid waste (MSW)

Processing facility
Facility at which workers hand sort commingled recyclable material as it passes by on a conveyor belt.

Facility that uses automated processes to separate recyclable materials from commingled recyclable materials or raw MSW.

All of the solid wastes generated in a community except for industrial process wastes and agricultural wastes. It generally includes discarded durable and nondurable goods; containers and packaging; food scraps; yard trimmings; and miscellaneous inorganic debris, including household hazardous wastes. MSW often includes construction and demolition debris and sludges and ashes generated by sewage treatment plants and MSW incinerators. Sources of MSW include households; commercial enterprises and industrial firms (for example, food market and office paper wastes); and institutions such as schools, transportation terminals, and hospitals. In developing countries MSW is often disposed of with ash, human wastes (where sewage systems do not reach substantial portions of the population), medical waste, and industrial process waste.

Transforms the physical characteristics of MSW by recycling, composting, burning, or compacting to reduce the threat it poses to human health and ecosystems, improve its disposability, and possibly capture value from the waste. 
Table 5

\section{Glossary of Technical Terms ${ }^{54}$}

Recycling The act of gathering and refining the by-products of production or consumption activities for use as inputs for production activities.

Residual Residual waste includes incinerator ash, materials that are not recyclable or not worth recycling, residues from waste recycling and composting processes, and unprocessed MSW, all of which are generally disposed of in landfills.

Sanitary Disposal of MSW in a manner designed to minimize impacts on human health and the environment. Generally landfill consists of a pit lined with clay and plastic to prevent leachate from seeping into groundwater, drainage pipes to draw off leachate for treatment, deposits of MSW in thin layers that are frequently covered with soil or other materials to prevent waste from blowing away or attracting pests and to keep out water, and a system to collect methane (a by-product of the anaerobic decomposition of MSW) to prevent explosions (the methane is either flared or used as fuel).

Transfer

A facility where MSW from collection vehicles is consolidated into larger loads that are transported by tractor station trailors, railroad, barges, or other means to processing facilities or landfills.

Windrows Rows of piled organic materials that are turned periodically to expose the materials to oxygen and to control the temperature to promote aerobic composting. 


\section{APPENDIX \\ Data Used in Regression Analyses}

Table D-1

Country Cross-section Data

1990
GDP per capita

(US\$)
1990 Population (millions)
1990 MSW generation per capita per day (lbs.)
Mozambique

Kenya

Cote d'Ivoire

Indonesia

Guatemala

Poland

Gabon

Colombia

Hungary

Romania

Greece

Bulgaria

Portugal

Trinidad and Tobago

Ireland

Spain

Israel

Belgium

New Zealand

Italy

Netherlands
620

1,120

1,540

2,350

2,920

4,530

4,590

4,950

6,190

6,780

7,340

7,900

7,950

8,510

9,130

10,840

11,940

12,950

13,490

14,550

14,600
15.7

24.2

11.9

178.2

9.2

38.2

1.1

32.3

10.6

23.2

10.1

8.8

10.4

1.2

3.5

39.0

4.7

10.0

3.4

57.7

14.9
1.1

1.1

1.1

1.3

1.1

1.3

1.1

1.2

1.6

1.3

1.5

1.3

1.5

1.1

2.0

1.9

2.4

2.0

4.0

1.5

2.6 
Table D-1

Country Cross-section Data

$$
\begin{aligned}
& 1990 \\
& \text { GDP per capita } \\
& \text { (US\$) }
\end{aligned}
$$

\begin{tabular}{|c|c|c|c|}
\hline Austria & 14,750 & 7.7 & 1.3 \\
\hline Singapore & 14,920 & 3.0 & 1.9 \\
\hline United Kingdom & 14,960 & 57.4 & 2.2 \\
\hline France & 15,200 & 56.4 & 4.0 \\
\hline Denmark & 15,380 & 5.1 & 2.6 \\
\hline Finland & 15,620 & 5.0 & 2.4 \\
\hline Sweden & 16,000 & 8.6 & 2.0 \\
\hline Australia & 16,050 & 17.1 & 4.2 \\
\hline West Germany & 16,290 & 79.5 & 1.8 \\
\hline United Arab Emirates & 16,590 & 1.6 & 2.4 \\
\hline Japan & 16,950 & 123.5 & 2.0 \\
\hline Norway & 17,220 & 4.2 & 2.9 \\
\hline Canada & 19,650 & 26.5 & 3.7 \\
\hline United States & 21,360 & 250.0 & 3.3 \\
\hline Switzerland & 21,690 & 6.7 & 2.2 \\
\hline \multicolumn{4}{|l|}{ Sources } \\
\hline
\end{tabular}

Population estimates: The World Bank 1992, pp. 218-219.
1990 Population (millions)
1990 MSW generation per capita per day (lbs.)


Table D-2

U.S. Time Series Data Used in Regressions

\begin{tabular}{|c|c|c|c|}
\hline Year & $\begin{array}{l}\text { GDP per capita } \\
\text { (US \$1987) }\end{array}$ & $\begin{array}{c}\text { Population } \\
\text { (millions) }\end{array}$ & $\begin{array}{c}\text { MSW } \\
\text { (millions of tons) }\end{array}$ \\
\hline 1970 & 14,021 & 205.1 & 121.9 \\
\hline 1971 & 14,276 & 207.7 & 126.1 \\
\hline 1972 & 14,803 & 209.9 & 132.8 \\
\hline 1973 & 15,425 & 211.9 & 137.9 \\
\hline 1974 & 15,185 & 213.9 & 137.8 \\
\hline 1975 & 14,915 & 216.0 & 128.1 \\
\hline 1976 & 15,508 & 218.0 & 138.0 \\
\hline 1977 & 16,045 & 220.2 & 141.6 \\
\hline 1978 & 16,637 & 222.6 & 145.6 \\
\hline 1979 & 16,867 & 225.1 & 151.4 \\
\hline 1980 & 16,577 & 227.8 & 151.4 \\
\hline 1981 & 16,702 & 230.1 & 153.1 \\
\hline 1982 & 16,173 & 232.5 & 149.9 \\
\hline 1983 & 16,638 & 234.8 & 157.2 \\
\hline 1984 & 17,504 & 237.0 & 163.4 \\
\hline 1985 & 17,885 & 239.3 & 164.4 \\
\hline 1986 & 18,238 & 241.5 & 169.1 \\
\hline 1987 & 18,614 & 243.9 & 175.8 \\
\hline 1988 & 19,158 & 246.3 & 181.4 \\
\hline
\end{tabular}

Sources

MSW generation rates: U.S. Environmental Protection Agency 1990 and 1992 spliced together with earlier and subsequently updated estimates (U.S. Bureau of the Census 1978, p. 214; 1983, p. 213; 1990, p. 206.

Real GDP per capita and population estimates: Economic Report of the President January 1993, pp. 348, 381. 
Table D-3

U.S Time Series Data: Original MSW Generation Data

\begin{tabular}{|c|c|c|c|c|c|}
\hline & Census 1978 & Census 1983 & Census 1990 & EPA 1990 & EPA 1992 \\
\hline 1970 & N/A & 131.1 & 120.5 & 121.9 & 121.9 \\
\hline 1971 & 132.9 & $132.0^{\circ}$ & $121.4^{*}$ & $124.8^{\circ}$ & $126.1^{*}$ \\
\hline 1972 & 139.3 & $138.3^{*}$ & $127.2^{*}$ & $131.5^{\circ}$ & $132.8^{\circ}$ \\
\hline 1973 & 144.2 & $143.2^{*}$ & $131.7^{\circ}$ & $136.6^{\circ}$ & $137.9^{\circ}$ \\
\hline 1974 & 144.1 & 143.1 & $131.6^{\circ}$ & $136.5^{\circ}$ & $137.8^{\circ}$ \\
\hline 1975 & 136.1 & 135.6 & 125.3 & 128.0 & 128.1 \\
\hline 1976 & 144.7 & 143.2 & $131.7^{*}$ & $136.6^{\circ}$ & $138.0^{\circ}$ \\
\hline 1977 & N/A & 146.6 & $134.9^{*}$ & $140.2^{\circ}$ & $141.6^{*}$ \\
\hline 1978 & N/A & 150.4 & $138.3^{*}$ & $144.2^{\circ}$ & $145.6^{\circ}$ \\
\hline 1979 & N/A & 155.8 & $143.3^{*}$ & $149.9^{\circ}$ & $151.4^{*}$ \\
\hline 1980 & N/A & 155.6 & 142.6 & 149.6 & 151.4 \\
\hline 1981 & N/A & $\mathrm{N} / \mathrm{A}$ & 144.8 & $151.6^{*}$ & $153.1^{*}$ \\
\hline 1982 & N/A & N/A & 142.0 & $148.4^{\circ}$ & $149.9^{*}$ \\
\hline 1983 & N/A & N/A & 148.3 & $155.7^{*}$ & $157.2^{*}$ \\
\hline 1984 & $\mathrm{~N} / \mathrm{A}$ & $\mathrm{N} / \mathrm{A}$ & 153.6 & $161.8^{\circ}$ & $163.4^{\circ}$ \\
\hline 1985 & N/A & N/A & 152.5 & 161.6 & 164.4 \\
\hline 1986 & N/A & $\mathrm{N} / \mathrm{A}$ & 157.7 & 167.4 & $169.1^{*}$ \\
\hline 1987 & $N / A$ & N/A & $\mathrm{N} / \mathrm{A}$ & 174.1 & $175.8^{\circ}$ \\
\hline 1988 & N/A & N/A & $\mathrm{N} / \mathrm{A}$ & 179.6 & $181.4^{\circ}$ \\
\hline
\end{tabular}

Key

Spliced data.

Census 1978: U.S. Bureau of the Census 1978, p. 214.

Census 1983: U.S. Bureau of the Census 1983, p. 213.

Census 1990: U.S. Bureau of the Census 1990, p. 206.

EPA 1990: U.S. Environmental Protection Agency 1990.

EPA 1992: U.S. Environmental Protection Agency 1990. 
Table D-4

U.S. Cross Section Data, by State: 1991

\begin{tabular}{|c|c|c|c|c|c|c|c|c|}
\hline & $\begin{array}{c}\text { Personal } \\
\text { Income Per } \\
\text { Capita } \\
(\$ 1991)\end{array}$ & $\begin{array}{l}\text { Population } \\
\text { (millions) }\end{array}$ & $\begin{array}{l}\text { SOME } \\
\text { IND }\end{array}$ & IND & $C \& D$ & $\begin{array}{c}\text { C\&D } \\
+ \\
\text { IND }\end{array}$ & $\begin{array}{c}\text { IND } \\
+ \\
\text { SS } \\
+ \\
\text { C\&D }\end{array}$ & $\begin{array}{l}\text { MSW Generation } \\
\text { (tons) }\end{array}$ \\
\hline MS & 13,210 & 2.593 & & & & & & $1,400,000$ \\
\hline AR & 14,458 & 2.373 & $\mathbf{X}$ & & & & & $2,000,000$ \\
\hline WV & 14,665 & 1.803 & & & & & & $1,700,000$ \\
\hline UT & 14,737 & 1.770 & & & & & & $1,200,000$ \\
\hline NM & 14,818 & 1.549 & & & & $\mathbf{X}$ & & $1,500,000$ \\
\hline LA & 15,067 & 4.254 & & & & & & $3,500,000$ \\
\hline KY & 15,442 & 3.713 & & & & & & $3,500,000$ \\
\hline $\mathrm{SC}$ & 15,469 & 3.560 & & & & & & $4,000,000$ \\
\hline ND & 15,594 & 0.635 & & & & & & 400,000 \\
\hline AL & 15,601 & 4.091 & & & & & $\mathrm{X}$ & $4,500,000$ \\
\hline OK & 15,656 & 3.175 & & & & $\mathbf{X}$ & & $3,000,000$ \\
\hline $\mathbf{M T}$ & 15,793 & 0.809 & & & $X$ & & & 600,000 \\
\hline ID & 15,854 & 1.040 & & & $X$ & & & 850,000 \\
\hline SD & 16,419 & 0.704 & & & & $\mathbf{X}$ & & 800,000 \\
\hline $\mathrm{TN}$ & 16,489 & 4.953 & $\mathbf{X}$ & & & & & $5,000,000$ \\
\hline$A Z$ & 16,760 & 3.748 & & & $\mathbf{X}$ & & & $2,900,000$ \\
\hline $\mathrm{NC}$ & 16,810 & 6.736 & & & $X$ & & & $6,000,000$ \\
\hline IA & 17,102 & 2.795 & & & & & $X$ & $2,300,000$ \\
\hline IN & 17,275 & 5.610 & $\mathbf{X}$ & & & & & $5,700,000$ \\
\hline $\mathrm{ME}$ & 17,330 & 1.234 & & & & & & 950,000 \\
\hline TX & 17,440 & 17.348 & & & $\mathbf{X}$ & & & $18,000,000$ \\
\hline
\end{tabular}


Table D-4

U.S. Cross Section Data, by State: 1991

\begin{tabular}{|c|c|c|c|c|c|c|c|c|}
\hline & $\begin{array}{l}\text { Personal } \\
\text { Income Per } \\
\text { Capita } \\
(\$ 1991)\end{array}$ & $\begin{array}{l}\text { Population } \\
\text { (millions) }\end{array}$ & $\begin{array}{l}\text { SOME } \\
\text { IND }\end{array}$ & IND & C\&D & $\begin{array}{c}\text { C\&D } \\
+ \\
\text { IND }\end{array}$ & $\begin{array}{c}\text { IND } \\
+ \\
\text { SS } \\
+ \\
\text { C\&D }\end{array}$ & $\begin{array}{l}\text { MSW Generation } \\
\text { (tons) }\end{array}$ \\
\hline GA & 17,636 & 6.623 & & & & & & $4,400,000$ \\
\hline OR & 17,789 & 2.922 & & & & & & $3,300,000$ \\
\hline VT & 17,811 & 0.567 & & & & & & 390,000 \\
\hline WI & 17,970 & 4.956 & & & & & & $3,400,000$ \\
\hline $\mathrm{OH}$ & 18,001 & 10.941 & & & & & $\mathrm{X}$ & $15,700,000$ \\
\hline NE & 18,047 & 1.593 & & & & & & $1,300,000$ \\
\hline MO & 18,105 & 5.157 & & & $\mathrm{X}$ & & & $7,500,000$ \\
\hline KS & 18,259 & 2.495 & & & & & & $2,400,000$ \\
\hline WY & 18,295 & 0.460 & & & $X$ & & & 320,000 \\
\hline MI & 18,693 & 9.380 & & $X$ & & & & $11,700,000$ \\
\hline FL & 19,203 & 13.266 & & & & & & $18,700,000$ \\
\hline $\mathrm{MN}$ & 19,289 & 4.432 & $\mathbf{X}$ & & & & & $4,400,000$ \\
\hline RI & 19,451 & 1.005 & & & & & & $1,200,000$ \\
\hline PA & 19,638 & 11.958 & & & & & & $9,500,000$ \\
\hline $\mathrm{CO}$ & 19,745 & 3.378 & & & & & $X$ & $2,400,000$ \\
\hline VA & 20,074 & 6.280 & & & & & & $9,000,000$ \\
\hline WA & 20,163 & 5.012 & & & & & & $5,100,000$ \\
\hline $\mathrm{DE}$ & 20,317 & 0.680 & & & & & & 750,000 \\
\hline IL & 20,622 & 11.541 & & & & & & $14,600,000$ \\
\hline NV & 20,774 & 1.283 & & & & & & $1,000,000$ \\
\hline $\mathrm{CA}$ & 20,880 & 30.380 & & & & & $X$ & $45,000,000$ \\
\hline
\end{tabular}




\begin{tabular}{|c|c|c|c|c|c|c|c|c|}
\hline \multicolumn{9}{|c|}{$\begin{array}{c}\text { Table D-4 } \\
\text { U.S. Cross Section Data, by State: } 1991\end{array}$} \\
\hline & $\begin{array}{c}\text { Personal } \\
\text { Income Per } \\
\text { Capita } \\
(\$ 1991)\end{array}$ & $\begin{array}{l}\text { Population } \\
\text { (millions) }\end{array}$ & $\begin{array}{l}\text { SOME } \\
\text { IND }\end{array}$ & IND & $C \& D$ & $\begin{array}{c}\text { C\&D } \\
+ \\
\text { IND }\end{array}$ & $\begin{array}{c}\text { IND } \\
+ \\
\text { SS } \\
+ \\
\text { C\&D }\end{array}$ & $\begin{array}{l}\text { MSW Generation } \\
\text { (tons) }\end{array}$ \\
\hline NH & 20,961 & 1.104 & & & & $\mathrm{X}$ & & $1,100,000$ \\
\hline $\mathrm{AK}$ & 21,592 & 0.570 & & & & & & 500,000 \\
\hline $\mathrm{HI}$ & 21,621 & 1.137 & & & & & $\mathrm{X}$ & $1,300,000$ \\
\hline $\mathrm{MD}$ & 22,483 & 4.859 & $\mathrm{x}$ & & & & & $5,100,000$ \\
\hline MA & 22,796 & 5.996 & & & $\mathrm{X}$ & & & $6,800,000$ \\
\hline NY & 22,925 & 18.055 & & & & & & $22,000,000$ \\
\hline $\mathrm{NJ}$ & 24,744 & 7.753 & & & & & & $7,100,000$ \\
\hline $\mathrm{CT}$ & 25,844 & 3.289 & & & & & & $2,900,000$ \\
\hline $\mathrm{DC}$ & 26,094 & 0.595 & & & & & & 815,000 \\
\hline
\end{tabular}

Sources

MSW generation rates: Glenn 1992, p. 47.

Population: U.S. Bureau of the Census 1993.

Per capita income: U.S. Bureau of Economic Analysis 1994.

Key

SOME IND: MSW generation estimate includes "some" industrial waste.

IND: MSW generation estimate includes industrial waste.

C\&D: MSW generation estimate includes construction and demolition waste.

IND + C\&D: MSW generation estimate includes industrial waste and construction and demolition waste.

IND + C\&D +SS: MSW generation estimate includes industrial waste, construction and demolition waste, and sewage sludge. 
Table D-5

U.S. Cross Section Data, by State: 1992

\begin{tabular}{|c|c|c|c|c|c|c|c|}
\hline & $\begin{array}{l}\text { Personal Income } \\
\text { Per Capita } \\
\text { (\$1992) }\end{array}$ & $\begin{array}{l}\text { SOME } \\
\text { IND }\end{array}$ & $\begin{array}{l}\text { SIG } \\
\text { IND }\end{array}$ & C\&D & $\begin{array}{l}\text { C\&D } \\
+ \\
\text { SS }\end{array}$ & Population & $\begin{array}{l}\text { MSW Generation } \\
\text { (tons) }\end{array}$ \\
\hline MS & 14,050 & & & & & $2,614,000$ & $1,400,000$ \\
\hline UT & 15,503 & & & & & $1,813,000$ & $1,500,000$ \\
\hline NM & 15,520 & & & & & $1,581,000$ & $1,487,000$ \\
\hline WV & 15,527 & & & & & $1,812,000$ & $1,700,000$ \\
\hline AR & 15,584 & $\mathrm{X}$ & & & & $2,399,000$ & $2,154,000$ \\
\hline $\mathrm{LA}$ & 15,852 & & & & & $4,287,000$ & $3,484,000$ \\
\hline SC & 16,171 & $\mathrm{X}$ & & & & $3,603,000$ & $5,000,000$ \\
\hline MT & 16,379 & & & & & 824,000 & 744,000 \\
\hline $\mathrm{KY}$ & 16,436 & & & & & $3,755,000$ & $4,650,000$ \\
\hline OK & 16,475 & & & & & $3,212,000$ & $3,000,000$ \\
\hline $\mathrm{AL}$ & 16,496 & & & & & $4,136,000$ & $5,200,000$ \\
\hline ID & 16,676 & & & & & $1,067,000$ & 850,000 \\
\hline ND & 17,127 & & & & & 636,000 & 466,000 \\
\hline $\mathrm{SD}$ & 17,344 & $\mathrm{X}$ & & & & 711,000 & 800,000 \\
\hline $\mathrm{AZ}$ & 17,483 & $\mathrm{X}$ & & & & $3,832,000$ & $4,147,000$ \\
\hline $\mathrm{TN}$ & 17,622 & & $\mathbf{X}$ & & & $5,024,000$ & $5,800,000$ \\
\hline $\mathrm{NC}$ & 17,828 & & $\mathbf{X}$ & & & $6,843,000$ & $7,788,000$ \\
\hline ME & 18,167 & & & & & $1,235,000$ & $1,246,000$ \\
\hline IA & 18,178 & & & & & $2,812,000$ & $2,088,000$ \\
\hline IN & 18,384 & & & & $\mathrm{X}$ & $5,662,000$ & $8,400,000$ \\
\hline $\mathrm{TX}$ & 18,449 & & & & & $17,656,000$ & $14,469,000$ \\
\hline GA & 18,472 & & & & & $6,751,000$ & $6,000,000$ \\
\hline
\end{tabular}


Table D-5

U.S. Cross Section Data, by State: 1992

\begin{tabular}{|c|c|c|c|c|c|c|c|}
\hline & $\begin{array}{l}\text { Personal Income } \\
\text { Per Capita } \\
\text { (\$1992) }\end{array}$ & $\begin{array}{l}\text { SOME } \\
\text { IND }\end{array}$ & $\begin{array}{l}\text { SIG } \\
\text { IND }\end{array}$ & $C \& D$ & $\begin{array}{c}\text { C\&D } \\
+ \\
\text { SS }\end{array}$ & Population & $\begin{array}{l}\text { MSW Generation } \\
\text { (tons) }\end{array}$ \\
\hline OR & 18,716 & $\mathrm{X}$ & & & & $2,977,000$ & $3,350,000$ \\
\hline VT & 18,801 & & & & & 570,000 & 550,000 \\
\hline WY & 18,871 & $\mathrm{X}$ & & & & 466,000 & 320,000 \\
\hline $\mathrm{OH}$ & 18,923 & & $\mathrm{X}$ & & & $11,016,000$ & $16,400,000$ \\
\hline MO & 18,965 & & & & & $5,193,000$ & $7,500,000$ \\
\hline WI & 19,115 & & & & & $5,007,000$ & $3,352,000$ \\
\hline KS & 19,219 & & & & & $2,523,000$ & $2,400,000$ \\
\hline NE & 19,228 & & & & & $1,606,000$ & $1,400,000$ \\
\hline MI & 19,681 & & & & $\mathrm{X}$ & $9,437,000$ & $13,000,000$ \\
\hline FL & 19,686 & & & $\mathrm{X}$ & & $13,488,000$ & $19,400,000$ \\
\hline $\mathbf{R I}$ & 20,229 & & & & & $1,005,000$ & $1,200,000$ \\
\hline $\mathrm{MN}$ & 20,513 & & & & & $4,480,000$ & $4,270,000$ \\
\hline $\mathrm{CO}$ & 20,577 & & & & & $3,470,000$ & $3,500,000$ \\
\hline PA & 20,601 & & & & & $12,009,000$ & $8,984,000$ \\
\hline VA & 20,870 & & & & & $6,377,000$ & $7,600,000$ \\
\hline $\mathrm{DE}$ & 21,102 & $\mathrm{X}$ & & & & 689,000 & 790,000 \\
\hline WA & 21,306 & & & & & $5,136,000$ & $5,708,000$ \\
\hline $\mathrm{CA}$ & 21,599 & & $\mathrm{X}$ & & & $30,867,000$ & $44,535,000$ \\
\hline NH & 21,729 & & & & $x$ & $1,111,000$ & $1,138,000$ \\
\hline IL & 21,781 & & $\mathrm{X}$ & & & $11,631,000$ & $14,140,000$ \\
\hline NV & 21,857 & & & & & $1,327,000$ & $2,300,000$ \\
\hline $\mathrm{AK}$ & 22,244 & & & & & 587,000 & 500,000 \\
\hline
\end{tabular}




\begin{tabular}{|c|c|c|c|c|c|c|c|}
\hline \multicolumn{8}{|c|}{$\begin{array}{c}\text { Table D-5 } \\
\text { U.S. Cross Section Data, by State: } 1992\end{array}$} \\
\hline & $\begin{array}{l}\text { Personal Income } \\
\text { Per Capita } \\
\text { (\$1992) }\end{array}$ & $\begin{array}{l}\text { SOME } \\
\text { IND }\end{array}$ & $\begin{array}{l}\text { SIG } \\
\text { IND }\end{array}$ & $C \& D$ & $\begin{array}{l}\text { C\&D } \\
+ \\
\text { SS }\end{array}$ & Population & $\begin{array}{l}\text { MSW Generation } \\
\text { (tons) }\end{array}$ \\
\hline HI & 22,420 & $\mathrm{X}$ & & & & $1,160,000$ & $1,300,000$ \\
\hline MD & 23,199 & & & & & $4,908,000$ & $5,000,000$ \\
\hline MA & 23,625 & & & & & $5,998,000$ & $6,600,000$ \\
\hline NY & 24,138 & & & $\mathrm{X}$ & & $18,119,000$ & $22,800,000$ \\
\hline NJ & 26,098 & & & & & $7,789,000$ & $7,513,000$ \\
\hline CT & 27,154 & & & & & $3,281,000$ & $2,900,000$ \\
\hline DC & 28,313 & & & & & 589,000 & 919,000 \\
\hline
\end{tabular}

\section{Sources}

MSW generation rates: Steuteville and Goldstein 1993, p. 46. Population: U.S. Bureau of the Census 1993. Per capita income: U.S. Bureau of Economic Analysis 1994.

Key

SOME IND: MSW generation estimate "includes some industrial waste."

SIG IND: MSW generation estimate "includes significant industrial waste."

C\&D: MSW generation estimate "includes [construction and demolition] waste."

C\&D+SS: MSW generation estimate "includes [construction and demolition waste] and sewage sludge." 
Table D-6

Chinese Cities Cross Section Data: 1990

GDP per capita (yuan)

Xining

Changchun

Yantai

Wuhan

Hohhot

Harbin

Nanchang

Xi'an

Chongqing

Yinchuan

Guiyang

Zhengzhou

Changsha

Hefei

Nanning

Taiyuan

Shantou

Shenyang

Shijiazhuang

Lanzhou

Wenzhou

Tianjin

Urumqi

Chengdu
2,645

3,478

3,650

3,733

3,859

4,003

4,024

4,028

4,296

4,438

4,475

4,586

4,915

4,925

4,972

5,026

5,043

5,133

5,187

5,314

5,323

5,530

5,587

5,657
GDP (bil. yuan)

1.46

5.84

1.65

12.26

2.52

9.78

4.37

7.89

9.74

1.58

4.56

5.32

5.47

3.61

3.59

7.71

2.92

18.50

5.54

6.35

2.14

25.30

5.85

9.69
Non-Agri.

Population

$$
552,000
$$

$1,679,000$

452,000

$3,284,000$

653,000

$2,443,000$

$1,086,000$

$1,959,000$

$2,267,000$

356,000

$1,019,000$

$1,160,000$

$1,113,000$

733,000

722,000

$1,534,000$

579,000

$3,604,000$

$1,068,000$

$1,195,000$

402,000

$4,575,000$

$1,047,000$

$1,713,000$
Total Population

650

650,000

$2,110,000$

805,000

$3,751,000$

886,000

$2,827,000$

$1,354,000$

$2,757,000$

$2,984,000$

480,000

$1,532,000$

$1,706,000$

$1,327,000$

$1,002,000$

$1,070,000$

$1,964,000$

856,000

$4,538,000$

$1,319,000$

$1,507,000$

562,000

$5,771,000$

$1,157,000$

$2,808,000$
MSW (metric tons)

236,000

$1,048,000$

156,000

$1,416,000$

380,000

$1,500,000$

187,000

580,000

400,000

210,000

513,000

603,000

290,000

190,000

171,000

950,000

218,000

$2,081,000$

390,000

460,000

211,000

$2,172,000$

760,000

619,000 
Table D-6

Chinese Cities Cross Section Data: 1990

\begin{tabular}{|c|c|c|c|c|c|}
\hline & $\begin{array}{r}\text { GDP per capita } \\
\text { (yuan) }\end{array}$ & $\begin{array}{r}\text { GDP (bil. } \\
\text { yuan) }\end{array}$ & $\begin{array}{l}\text { Non-Agri. } \\
\text { Population }\end{array}$ & Total Population & $\begin{array}{r}\text { MSW (metric } \\
\text { tons) }\end{array}$ \\
\hline Lianyungang & 5,678 & 2.01 & 354,000 & 521,000 & 151,000 \\
\hline Fuzhou & 5,703 & 4.99 & 875,000 & $1,292,000$ & 347,000 \\
\hline Beihai & 6,106 & 0.69 & 113,000 & 200,000 & 57,000 \\
\hline Nanjing & 6,163 & 12.88 & $2,090,000$ & $2,498,000$ & 608,000 \\
\hline Haikou & 6,214 & 1.74 & 280,000 & 370,000 & 144,000 \\
\hline Kunming & 6,236 & 7.04 & $1,129,000$ & $1,525,000$ & 492,000 \\
\hline Jinan & 6,354 & 9.27 & $1,459,000$ & $2,323,000$ & 620,000 \\
\hline Qingdao & 6,463 & 9.43 & $1,459,000$ & $2,058,000$ & 508,000 \\
\hline Shanghai & 6,825 & 51.17 & $7,497,000$ & $7,835,000$ & $2,786,000$ \\
\hline Qinhuangdao & 7,123 & 2.60 & 365,000 & 501,000 & 326,000 \\
\hline Hangzhou & 7,736 & 8.51 & $1,100,000$ & $1,339,000$ & 486,000 \\
\hline Beijing & 7,747 & 44.70 & $5,770,000$ & $6,995,000$ & $3,445,000$ \\
\hline Dalian & 7,876 & 13.57 & $1,723,000$ & $2,396,000$ & 702,000 \\
\hline Zhanjiang & 8,055 & 3.23 & 401,000 & $1,060,000$ & 214,000 \\
\hline Nantong & 8,630 & 2.96 & 343,000 & 457,000 & 99,000 \\
\hline Guangzhou & 8,874 & 25.86 & $2,914,000$ & $3,579,000$ & $1,052,000$ \\
\hline Ningbo & 9,765 & 5.40 & 553,000 & $1,085,000$ & 311,000 \\
\hline Weihai & 9,767 & 1.26 & 129,000 & 257,000 & 52,000 \\
\hline Xiamen & 11,860 & 4.59 & 387,000 & 603,000 & 230,000 \\
\hline Zhuhai & 21,333 & 3.52 & 165,000 & 366,000 & 138,000 \\
\hline Shenzhen & 30,655 & 10.76 & 351,000 & 395,000 & 256,000 \\
\hline
\end{tabular}

Source: State Statistical Bureau of the People's Republic of China 1991, pp. 593-611, 621. GDP per capita is GDP divided by the non-agricultural population of each city. "MSW" is metric tons of "residential garbage cleared". 
Table D-7

Taiwan Time Series Data

$\begin{array}{ccccc}\text { Year } & \begin{array}{c}\text { GDP (bil. } 1986 \text { N.T. } \\ \$ \text { ) }\end{array} & \begin{array}{c}\text { Total } \\ \text { Population }\end{array} & \begin{array}{c}\text { Population Receiving } \\ \text { MSW } \\ \text { Collection Services }\end{array} & \begin{array}{c}\text { Daily MSW } \\ \text { Collection (metric } \\ \text { tons) }\end{array} \\ 1980 & 1,848 & 17,805,000 & 14,644,000 & 8,736 \\ 1981 & 1,962 & 18,136,000 & 15,610,000 & 9,761 \\ 1982 & 2,032 & 18,458,000 & 16,276,000 & 10,589 \\ 1983 & 2,203 & 18,733,000 & 16,894,000 & 11,074 \\ 1984 & 2,437 & 19,013,000 & 17,443,000 & 11,725 \\ 1985 & 2,557 & 19,258,000 & 17,803,000 & 13,233 \\ 1986 & 2,855 & 19,455,000 & 18,119,000 & 13,954 \\ 1987 & 3,207 & 19,673,000 & 18,426,000 & 14,475 \\ 1988 & 3,443 & 19,904,000 & 18,734,000 & 16,116 \\ 1989 & 3,703 & 20,107,000 & 19,132,000 & 17,147 \\ 1990 & 3,884 & 20,353,000 & 19,468,000 & 18,753 \\ 1991 & 4,165 & 20,557,000 & 19,823,000 & 19,833\end{array}$

Source: Republic of China 1992, pp. 160-61, 11, 130-31.

GDP is in 1986 Taiwan Dollars. 
Table D-8

Gallup Poll and Related Data on Attitudes Toward MSW Generation and Management

$\begin{array}{ccc}\text { GDP Per } & \\ \text { Capita } & \text { Population } \\ \text { Country } & & \text { (1991) }\end{array}$

Percent Concerned About Wastefulness

19,320

22,130

17,170

17,880

16,820

16,130

21,780

16,340

11,430

19,390

19,770

6,080

9,450

4,500

6,930

7,170

1,150

4,840

8,320

5,240

7,060

1,360
27.3

252.7

4.3

5.2

15.1

5.0

6.8

57.6

3.5

123.9

80.1

10.3

9.9

38.2

148.7

83.3

866.5

57.3

43.3

151.4

13.4

99.0
68

73

47

44

31

40

55

60

57

41

68

37

46

36

53

69

47

57

61

58

54

52
Percent

Concerned About Inadequate Sanitation

$\begin{array}{ll}\text { Brazil } & 5,240 \\ \text { Chile } & 7,060 \\ \text { Nigeria } & 1,360\end{array}$

21

17

11

3

2

12

8

21

13

15

14

17

32

55

40

39

46

62

40

49

33

52 


\section{Table D-8}

Gallup Poll and Related Data on Attitudes Toward

MSW Generation and Management

$\begin{array}{ccc} & \text { GDP Per } & \\ \text { Capita } & \text { Population } \\ \text { Country } & & (1991)\end{array}$

Philippines

Uruguay
2,440

6,670
(1991)
Percent Concerned

About Wastefulness

\author{
Percent \\ Concerned About \\ Inadequate Sanitation
}

62.9

3.1
66

35
30

25

\section{Sources}

GDP per capita: Regression-based estimates of per capita GDP adjusted for purchasing power of currencies (rather than exchange rates), The World Bank 1993, pp. 296-297.

Population: The World Bank 1993, pp. 238-239.

Percent concerned about wastefulness: Percent of respondents who said that people who "use more resources than they need" and who "throw away too much" contribute a "great deal" to their nation's environmental problems (Dunlap, Gallup, and Gallup 1993a, figure 7d).

Percent concerned about inadequate sanitation: Percent of respondents who said that "inadequate sewage, sanitation and garbage disposal" was a "very serious" problem (Dunlap, Gallup, and Gallup 1993, figure 9c). 


\begin{tabular}{|c|c|c|c|c|c|c|c|c|c|}
\hline & Dat & Used to & Estimate & $\begin{array}{l}\text { able D-9 } \\
\text { d Project }\end{array}$ & Global MSW & Generat & on & & \\
\hline & $\begin{array}{c}\text { MSW Gen. } \\
\text { Per } \\
\text { Capita } \\
\text { (kgs/day) }\end{array}$ & $\begin{array}{l}\text { Pop. } \\
\text { (mil.) }\end{array}$ & $\begin{array}{c}\text { GDP Per } \\
\text { Capita } \\
\text { (USS) }\end{array}$ & $\begin{array}{l}\text { Total } \\
\text { MSW } \\
\text { Gen. } \\
\text { (mil. } \\
\text { metric } \\
\text { tons) }\end{array}$ & $\begin{array}{l}\text { Ave. } \\
\text { Ann. } \\
\text { GDP } \\
\text { Growth, } \\
1980-90 \\
\text { (pct) }\end{array}$ & $\begin{array}{l}\text { Proj. } \\
\text { Ann. } \\
\text { Pop. } \\
\text { Growth } \\
1989- \\
2000 \\
\text { (pct) }\end{array}$ & $\begin{array}{l}\text { Proj. } \\
\text { Pop. } \\
2000\end{array}$ & $\begin{array}{l}\text { Proj. } \\
\text { Pop. } \\
2025\end{array}$ & $\begin{array}{l}\text { Proj. } \\
\text { Ann. } \\
\text { Pop. } \\
\text { Growth } \\
2000- \\
2025 \\
\text { (pct) }\end{array}$ \\
\hline \multicolumn{10}{|c|}{ Low-Income Economies } \\
\hline Mozambique & 0.50 & 15.7 & 620 & $2.87^{\circ}$ & -0.7 & 3.0 & 21 & 42 & 2.8 \\
\hline Tanzania & & 24.5 & 540 & 2.99 & 2.8 & 3.1 & 33 & 64 & 2.7 \\
\hline Ethiopia & & 51.2 & 310 & 5.33 & 1.8 & 3.4 & 72 & 156 & 3.2 \\
\hline Somalia & & 7.8 & 540 & 0.91 & 2.4 & 3.1 & 11 & 21 & 2.8 \\
\hline Nepal & & 18.9 & 950 & 2.77 & 4.6 & 2.5 & 24 & 37 & 1.7 \\
\hline Chad & & 5.7 & 440 & 0.61 & 5.9 & 2.7 & 7 & 14 & 2.6 \\
\hline Bhutan & & 1.4 & 520 & 0.15 & 7.5 & $2 \cdot 4$ & 2 & 3 & 2.1 \\
\hline Lao PDR & & 4.1 & $1,568^{\circ}$ & 0.67 & 0.0 & 3.2 & 6 & 10 & 2.3 \\
\hline Malawi & & 8.5 & 670 & 1.07 & 2.9 & 3.4 & 12 & 24 & 2.9 \\
\hline Bangladesh & & 106.7 & 1,050 & 17.32 & 4.3 & 1.8 & 128 & 176 & 1.3 \\
\hline Burundi & & 5.4 & 600 & 0.64 & 3.9 & 3.1 & 7 & 14 & 2.6 \\
\hline Zaire & & 37.3 & 950 & 5.61 & 1.8 & 3.0 & 50 & 89 & 2.3 \\
\hline Uganda & & 16.3 & 800 & 2.24 & 2.8 & 3.3 & 23 & 42 & 2.5 \\
\hline Madagascar & & 11.7 & 740 & 1.54 & 1.1 & 2.8 & 15 & 26 & 2.1 \\
\hline $\begin{array}{l}\text { Sierra } \\
\text { Leone }\end{array}$ & & 4.1 & 580 & 0.48 & 1.5 & 2.6 & 5 & 10 & 2.6 \\
\hline $\operatorname{Mali}$ & & 8.5 & 560 & 1.01 & 4.0 & 3.0 & 11 & 23 & 2.8 \\
\hline Nigeria & & 115.5 & 1,420 & 20.84 & 1.4 & 2.8 & 152 & 255 & 2.1 \\
\hline Niger & & 7.7 & 590 & 0.93 & -1.3 & 3.3 & 11 & 24 & 3.3 \\
\hline Rwanda & & 7.1 & 610 & 0.86 & 1.0 & 3.9 & 10 & 23 & 3.2 \\
\hline $\begin{array}{l}\text { Burkina } \\
\text { Faso }\end{array}$ & & 9.0 & 560 & 1.07 & 4.3 & 2.9 & 12 & 22 & 2.5 \\
\hline India & & 849.5 & 1,150 & 154.56 & 5.3 & 1.7 & 1005 & 1348 & 1.2 \\
\hline Benin & & 4.7 & 1,130 & 0.69 & 2.8 & 2.9 & 6 & 10 & 1.9 \\
\hline China & & 1133.7 & 1,950 & 249.70 & 9.5 & 1.3 & 1290 & 1597 & 0.9 \\
\hline Maiti & & 6.5 & 960 & 0.92 & -0.6 & 1.9 & 8 & 11 & 1.4 \\
\hline Kenya & 0.50 & 24.2 & 1,120 & $4.42^{\circ}$ & 4.2 & 3.5 & 34 & 64 & 2.5 \\
\hline
\end{tabular}




\begin{tabular}{|c|c|c|c|c|c|c|c|c|c|}
\hline & Dat & Used to & Estimate & $\begin{array}{c}\text { Table } D-9 \\
\text { and Project }\end{array}$ & Global MSV & Genera & & & \\
\hline & $\begin{array}{c}\text { MSW Gen. } \\
\text { Per } \\
\text { Capita } \\
\text { (kgs/day) }\end{array}$ & $\begin{array}{l}\text { Pop. } \\
\text { (mil.) }\end{array}$ & $\begin{array}{c}\text { GDP Per } \\
\text { Capita } \\
\text { (US\$) }\end{array}$ & $\begin{array}{c}\text { Total } \\
\text { MSW } \\
\text { Gen. } \\
\text { (mil. } \\
\text { metric } \\
\text { tons) }\end{array}$ & $\begin{array}{c}\text { Ave. } \\
\text { Ann. } \\
\text { GDP } \\
\text { Growth, } \\
1980-90 \\
\text { (pct) }\end{array}$ & $\begin{array}{c}\text { Proj. } \\
\text { Ann. } \\
\text { Pop. } \\
\text { Growth } \\
1989- \\
2000 \\
\text { (pct) }\end{array}$ & $\begin{array}{l}\text { Proj. } \\
\text { Pop. } \\
2000\end{array}$ & $\begin{array}{l}\text { Proj. } \\
\text { Pop. } \\
2025\end{array}$ & $\begin{array}{l}\text { Proj. } \\
\text { Ann. } \\
\text { Pop. } \\
\text { Growth } \\
2000- \\
2025 \\
\text { (pct) }\end{array}$ \\
\hline Pakistan & & 112.4 & 1,770 & 21.84 & 6.3 & 2.7 & 147 & 240 & 2.0 \\
\hline Ghana & & 14.9 & 1,720 & 2.64 & 3.0 & 3.0 & 20 & 34 & 2.1 \\
\hline $\begin{array}{l}\text { Cent. Afr. } \\
\text { Rep. }\end{array}$ & & 3.0 & 900 & 0.40 & 1.5 & 2.5 & 4 & 6 & 1.8 \\
\hline Togo & & 3.6 & 990 & 0.50 & 1.6 & 3.2 & 5 & 9 & 2.4 \\
\hline Zambia & & 8.1 & 810 & 1.09 & 0.8 & 3.1 & 11 & 20 & 2.4 \\
\hline Guinea & & 5.7 & $1,568^{2}$ & 0.94 & 0.0 & 2.8 & 8 & 15 & 2.8 \\
\hline Sri Lanka & & 17.0 & 2,370 & 3.38 & 4.0 & 1.1 & 19 & 24 & 0.9 \\
\hline Mauritania & & 2.0 & 1,240 & 0.29 & 1.4 & 2.8 & 3 & 5 & 2.6 \\
\hline Lesotho & & 1.8 & 1,700 & 0.29 & 3.1 & 2.6 & 2 & 4 & 2.2 \\
\hline Indonesia & 0.59 & 178.2 & 2,350 & $38.38^{\circ}$ & 5.5 & 1.6 & 209 & 275 & 1.1 \\
\hline Honduras & & 5.1 & 1,610 & 0.85 & 2.3 & 2.9 & 7 & 11 & 1.9 \\
\hline Egypt & & 52.1 & 3,100 & 11.88 & 5.0 & 1.8 & 62 & 86 & 1.3 \\
\hline $\begin{array}{l}\text { Afghani- } \\
\text { stan }\end{array}$ & & 16.4 & $1,568^{\circ}$ & 2.83 & 0.0 & 0.0 & 16 & 16.4 & 0.0 \\
\hline Cambodia & & 8.5 & $1,568^{\circ}$ & 1.43 & 0.0 & 1.9 & 10 & 14 & 1.3 \\
\hline Liberia & 0.50 & 2.6 & $1.568^{\circ}$ & $0.47^{\circ}$ & 0.0 & 3.0 & 3 & 6 & 2.2 \\
\hline Myanmar & & 41.6 & $1,568^{2}$ & 7.45 & 0.0 & 2.0 & 51 & 70 & 1.3 \\
\hline Sudan & & 25.1 & 1,180 & 4.00 & 0.0 & 2.8 & 33 & 55 & 2.1 \\
\hline Viet Nam & & 66.3 & $1,568^{\circ}$ & 12.10 & 0.0 & 2.1 & 82 & 116 & 1.4 \\
\hline \multicolumn{10}{|c|}{ Middle-Income Economies } \\
\hline Bolivia & & 7.2 & 1,910 & 1.29 & -0.1 & 2.5 & 9 & 14 & 1.7 \\
\hline Zimbabwe & & 9.8 & 1,970 & 1.79 & 2.9 & 2.4 & 12 & 18 & 1.5 \\
\hline Senegal & & 7.4 & 1,360 & 1.18 & 3.0 & 3.1 & 10 & 19 & 2.6 \\
\hline $\begin{array}{l}\text { Philip- } \\
\text { pines }\end{array}$ & & 61.5 & 2.320 & 12.79 & 0.9 & 1.8 & 74 & 101 & 1.3 \\
\hline $\begin{array}{l}\text { Cote } \\
\text { d'Ivoire }\end{array}$ & 0.50 & 11.9 & 1.540 & $2.17^{\circ}$ & 0.5 & 3.5 & 17 & 31 & 2.5 \\
\hline $\begin{array}{l}\text { Dominican } \\
\text { Rep. }\end{array}$ & & 7.1 & 2,860 & 1.45 & 2.1 & 1.6 & 8 & 11 & 1.1 \\
\hline
\end{tabular}




\begin{tabular}{|c|c|c|c|c|c|c|c|c|c|}
\hline & Data & Used to & Estimate & $\begin{array}{l}\text { Table D-9 } \\
\text { and Project }\end{array}$ & Global MSW & Generat & on & & \\
\hline & $\begin{array}{c}\text { MSW Gen. } \\
\text { Per } \\
\text { Capita } \\
\text { (kgs/day) }\end{array}$ & $\begin{array}{l}\text { POP. } \\
(\mathrm{mil} .)\end{array}$ & $\begin{array}{c}\text { GDP Per } \\
\text { Capita } \\
\text { (USS) }\end{array}$ & $\begin{array}{l}\text { Total } \\
\text { MSw } \\
\text { Gen. } \\
\text { (mil. } \\
\text { metric } \\
\text { tons) }\end{array}$ & $\begin{array}{l}\text { Ave. } \\
\text { Ann. } \\
\text { GDP } \\
\text { Growth, } \\
1980-90 \\
\text { (pct) }\end{array}$ & $\begin{array}{l}\text { Proj. } \\
\text { Ann. } \\
\text { Pop. } \\
\text { Growth } \\
1989- \\
2000 \\
\text { (pct) }\end{array}$ & $\begin{array}{l}\text { Proj. } \\
\text { Pop. } \\
2000\end{array}$ & $\begin{array}{l}\text { Proj. } \\
\text { Pop. } \\
2025\end{array}$ & $\begin{array}{l}\text { Proj. } \\
\text { Ann. } \\
\text { Pop. } \\
\text { Growth } \\
2000- \\
2025 \\
\text { (pct) }\end{array}$ \\
\hline $\begin{array}{l}\text { Papua New } \\
\text { Guinea }\end{array}$ & & 3.9 & 1,500 & 0.63 & 1.9 & 2.3 & 5 & 7 & 1.4 \\
\hline Guatemala & 0.50 & 9.2 & 2,920 & $1.68^{\circ}$ & 0.8 & 2.8 & 12 & 20 & 2.0 \\
\hline Morocco & & 25.1 & 2,670 & 5.28 & 4.0 & 2.4 & 32 & 47 & 1.6 \\
\hline Cameroon & & 11.7 & 2,020 & 2.17 & 2.3 & 2.9 & 16 & 28 & 2.4 \\
\hline Ecuador & & 10.3 & 3,720 & 2.34 & 2.0 & 2.0 & 13 & 18 & 1.5 \\
\hline Syria & & 12.4 & 4,110 & 2.94 & 2.1 & 3.6 & 18 & 35 & 2.8 \\
\hline Congo & & 2.3 & 2,690 & 0.44 & 3.6 & 3.3 & 3 & 6 & 2.6 \\
\hline El Salvador & & 5.2 & 1,890 & 0.91 & 0.9 & 1.8 & 6 & 9 & 1.5 \\
\hline Paraguay & & 4.3 & 3,120 & 0.89 & 2.5 & 2.8 & 6 & 10 & 2.3 \\
\hline Peru & & 21.7 & 2,720 & 4.57 & -0.3 & 2.0 & 26 & 37 & 1.4 \\
\hline Jordan & & 3.2 & 4.530 & 0.74 & 0.0 & 3.8 & 5 & 10 & 3.1 \\
\hline Colombia & 0.55 & 32.3 & 4,950 & $6.48^{\circ}$ & 3.7 & 1.5 & 37 & 50 & 1.2 \\
\hline Thailand & & 55.8 & 4,610 & 14.60 & 7.6 & 1.4 & 64 & 84 & 1.1 \\
\hline Tunisia & & 8.1 & 3,979 & 1.87 & 3.6 & 1.9 & 10 & 14 & 1.4 \\
\hline Jamaica & & $2 \cdot 4$ & 3,030 & 0.48 & 1.6 & 0.7 & 3 & 3 & 0.6 \\
\hline Turkey & & 56.1 & 5,020 & 15.11 & 5.1 & 1.9 & 68 & 91 & 1.2 \\
\hline Romania & 0.59 & 23.2 & 6,780 & $5.00^{\circ}$ & 1.2 & 0.4 & 24 & 27 & 0.4 \\
\hline Poland & 0.59 & 38.2 & 4,530 & $8.23^{\circ}$ & 1.8 & 0.4 & 40 & 44 & 0.4 \\
\hline Panama & & 2.4 & 4,120 & 0.53 & 0.2 & 1.6 & 3 & 4 & 1.4 \\
\hline Costa Rica & & 2.8 & 4,870 & 0.66 & 3.0 & 1.9 & 3 & 5 & 1.6 \\
\hline Chile & & 13.2 & 6,190 & 3.60 & 3.2 & 1.3 & 15 & 19 & 0.9 \\
\hline Botswana & & 1.3 & 4,300 & 0.29 & 11.3 & 2.5 & 2 & 2 & 0.7 \\
\hline Algeria & & 25.1 & 4,680 & 6.39 & 3.1 & 2.8 & 33 & 52 & 1.8 \\
\hline Bulgaria & 0.59 & 8.8 & 7,900 & $1.90^{\circ}$ & 2.6 & -0.2 & 9 & 9 & 0.2 \\
\hline Mauritius & & 1.1 & 6,500 & 0.28 & 6.0 & 0.9 & 1 & 1 & -0.7 \\
\hline Malaysia & & 17.9 & 5,900 & 4.87 & 5.2 & 2.3 & 22 & 32 & 1.4 \\
\hline Argentina & & 32.3 & 4,680 & 8.31 & -0.4 & 1.0 & 36 & 44 & 0.8 \\
\hline
\end{tabular}




\begin{tabular}{|c|c|c|c|c|c|c|c|c|c|}
\hline & Data & Used to & Estimate & $\begin{array}{l}\text { Table D-9 } \\
\text { and Project }\end{array}$ & Global MSW & Generat & on & & \\
\hline & $\begin{array}{c}\text { MSW Gen. } \\
\text { Per } \\
\text { Capita } \\
\text { (kgs/day) }\end{array}$ & $\begin{array}{l}\text { Pop. } \\
\text { (mil.) }\end{array}$ & $\begin{array}{c}\text { GDP Per } \\
\text { Capita } \\
\text { (Us\$) }\end{array}$ & $\begin{array}{l}\text { Total } \\
\text { MSw } \\
\text { Gen. } \\
\text { (mil. } \\
\text { metric } \\
\text { tons) }\end{array}$ & $\begin{array}{l}\text { Ave. } \\
\text { Ann. } \\
\text { GDP } \\
\text { Growth, } \\
1980-90 \\
\text { (pct) }\end{array}$ & $\begin{array}{l}\text { Proj. } \\
\text { Ann. } \\
\text { Pop. } \\
\text { Growth } \\
1989- \\
2000 \\
\text { (pct) }\end{array}$ & $\begin{array}{l}\text { Proj. } \\
\text { Pop. } \\
2000\end{array}$ & $\begin{array}{l}\text { Proj. } \\
\text { Pop. } \\
2025\end{array}$ & $\begin{array}{l}\text { Proj. } \\
\text { Ann. } \\
\text { Pop. } \\
\text { Growth } \\
2000- \\
2025 \\
\text { (pct) }\end{array}$ \\
\hline Iran & & 55.8 & 4,360 & 14.32 & 2.5 & 3.4 & 78 & 166 & 3.1 \\
\hline Albania & 0.59 & 3.3 & $4,084^{\circ}$ & $0.71^{\circ}$ & 0.0 & 1.5 & 4 & 5 & 1.1 \\
\hline Angola & & 10.0 & $4,084^{b}$ & 2.34 & 0.0 & 3.0 & 13 & 27 & 2.8 \\
\hline Lebanon & & 3.4 & $4,084^{\circ}$ & 0.76 & 0.0 & 0.0 & 3 & 3.4 & 0.0 \\
\hline Mongolia & & 2.1 & $4,084^{\circ}$ & 0.46 & 5.6 & 2.5 & 3 & 4 & 1.6 \\
\hline Namibia & & 1.8 & $4,084^{b}$ & 0.39 & 0.4 & 3.0 & 2 & 4 & 2.0 \\
\hline Nicaragua & & 3.9 & $4,084^{\circ}$ & 0.88 & -2.2 & 3.0 & 5 & 9 & 2.2 \\
\hline Yemen, Rep. & & 11.3 & $4,084^{b}$ & 2.66 & 0.0 & 3.7 & 16 & 37 & 3.3 \\
\hline \multicolumn{10}{|c|}{ Upper-Middle Income Economies } \\
\hline Mexico & & 86.2 & 5,980 & 25.07 & 1.0 & 1.8 & 103 & 142 & $1 \cdot 3$ \\
\hline $\begin{array}{l}\text { South } \\
\text { Africa }\end{array}$ & & 35.9 & 5,500 & 9.80 & 1.3 & 2.2 & 45 & 65 & 1.5 \\
\hline Venezuela & & 19.7 & 6,740 & 5.62 & 1.0 & 2.1 & 24 & 34 & 1.4 \\
\hline Uruguay & & 3.1 & 6,000 & 0.79 & 0.3 & 0.6 & 3 & 4 & 0.8 \\
\hline Brazil & & 150.4 & 4,780 & 41.45 & 2.7 & 1.7 & 178 & 237 & 1.2 \\
\hline Hungary & 0.73 & 10.6 & 6,190 & 2.82 & 1.3 & -0.4 & 10 & 10 & -0.1 \\
\hline Yugoslavia & & 23.8 & 5,090 & 6.22 & 0.8 & 0.6 & 25 & 28 & 0.4 \\
\hline $\begin{array}{l}\text { Czecho- } \\
\text { slovakia }\end{array}$ & 0.59 & 15.7 & $5,691^{\circ}$ & $3.38^{\circ}$ & 1.4 & 0.3 & 16 & 17 & 0.2 \\
\hline Gabon & 0.50 & 1.1 & 4,590 & $0.20^{\circ}$ & 2.3 & 2.8 & 1 & 3 & 3.0 \\
\hline $\begin{array}{l}\text { Trinidad } \\
\text { and Tobago }\end{array}$ & 0.50 & 1.2 & 8,510 & $0.22^{\circ}$ & -4.7 & 1.0 & 1 & 2 & 1.7 \\
\hline Portugal & 0.68 & 10.4 & 7,950 & $2.58^{\circ}$ & 2.7 & 0.4 & 11 & 11 & 0.1 \\
\hline Korea, Rep. & & 42.8 & 7,190 & 12.89 & 9.7 & 0.9 & 47 & 54 & 0.6 \\
\hline Greece & 0.68 & 10.1 & 7,340 & $2.51^{\circ}$ & 1.8 & 0.2 & 10 & 10 & -0.1 \\
\hline $\begin{array}{l}\text { Saudia } \\
\text { Arabia }\end{array}$ & 1.09 & 14.9 & $5,691^{\mathrm{c}}$ & $5.93^{\circ}$ & -1.8 & 3.7 & 21 & 43 & 2.8 \\
\hline Iraq & 1.09 & 18.9 & $5,691^{\circ}$ & $7.52^{\circ}$ & 0.0 & 3.4 & 26 & 48 & 2.4 \\
\hline Libya & & 4.5 & $5,691^{\circ}$ & 1.14 & 0.0 & 3.6 & 6 & 14 & 3.2 \\
\hline
\end{tabular}




\begin{tabular}{|c|c|c|c|c|c|c|c|c|c|}
\hline & Dat & Used to & Estimate & $\begin{array}{l}\text { Table D-9 } \\
\text { and Project }\end{array}$ & Global MSW & Generat & on & & \\
\hline & $\begin{array}{c}\text { MSW Gen. } \\
\text { Per } \\
\text { Capita } \\
(\mathrm{kgg} / \text { day })\end{array}$ & $\begin{array}{l}\text { Pop. } \\
\text { (mil.) }\end{array}$ & $\begin{array}{c}\text { GDP Per } \\
\text { Capita } \\
\text { (US\$) }\end{array}$ & $\begin{array}{l}\text { Total } \\
\text { MSw } \\
\text { Gen. } \\
\text { (mil. } \\
\text { metric } \\
\text { tons) }\end{array}$ & $\begin{array}{l}\text { Ave. } \\
\text { Ann . } \\
\text { GDP } \\
\text { Growth, } \\
1980-90 \\
\text { (pct) }\end{array}$ & $\begin{array}{l}\text { Proj. } \\
\text { Ann. } \\
\text { Pop. } \\
\text { Growth } \\
1989- \\
2000 \\
\text { (pct) }\end{array}$ & $\begin{array}{l}\text { Proj. } \\
\text { Pop. } \\
2000\end{array}$ & $\begin{array}{l}\text { Proj. } \\
\text { Pop. } \\
2025\end{array}$ & $\begin{array}{l}\text { Proj. } \\
\text { Ann. } \\
\text { Pop. } \\
\text { Growth } \\
2000- \\
2025 \\
\text { (pct) }\end{array}$ \\
\hline Oman & 1.09 & 1.6 & $5,691^{\circ}$ & $0.64^{\circ}$ & 12.8 & 3.9 & 2 & 5 & 3.1 \\
\hline \multicolumn{10}{|c|}{ High-Income Economies } \\
\hline Ireland & 0.91 & 3.5 & 9,130 & $1.16^{\circ}$ & 3.1 & 0.1 & 4 & 4 & 0.5 \\
\hline Israel & 1.09 & 4.7 & 11,940 & $1.87^{\circ}$ & 3.2 & 3.3 & 7 & 8 & 0.8 \\
\hline Spain & 0.86 & 39.0 & 10,840 & $12.24^{\circ}$ & 3.1 & 0.2 & 40 & 40 & 0.0 \\
\hline Singapore & 0.86 & 3.0 & 14,920 & $0.94^{\circ}$ & 6.4 & $1 \cdot 2$ & 3 & 4 & 0.7 \\
\hline Hong Kong & & 5.8 & 16,230 & 2.13 & 7.1 & 0.8 & 6 & 7 & 0.4 \\
\hline New Zeal and & 1.82 & 3.4 & 13,490 & $2.26^{\circ}$ & 1.9 & 0.7 & 4 & 4 & 0.4 \\
\hline Belgium & 0.91 & 10.0 & 12,950 & $3.32^{\circ}$ & 2.0 & 0.1 & 10 & 10 & 0.0 \\
\hline $\begin{array}{l}\text { United } \\
\text { Kingdom }\end{array}$ & 1.00 & 57.4 & 14,960 & $20.95^{\circ}$ & 3.1 & 0.2 & 59 & 61 & 0.2 \\
\hline Italy & 0.68 & 57.7 & 14,550 & $14.32^{\circ}$ & 2.4 & 0.1 & 58 & 55 & -0.2 \\
\hline Australia & 1.91 & 17.1 & 16,050 & $11.92^{\circ}$ & 3.4 & 1.4 & 20 & 23 & 0.6 \\
\hline $\begin{array}{l}\text { Nether- } \\
\text { lands }\end{array}$ & 1.18 & 14.9 & 14,600 & $6.42^{\circ}$ & 1.9 & 0.5 & 16 & 16 & 0.1 \\
\hline Austria & 0.59 & 7.7 & 14,750 & $1.66^{\circ}$ & 2.1 & 0.2 & 8 & 8 & 0.1 \\
\hline France & 1.82 & 56.4 & 15,200 & $37.47^{\circ}$ & 2.2 & 0.4 & 59 & 63 & 0.3 \\
\hline $\begin{array}{l}\text { United Arab } \\
\text { Emirates }\end{array}$ & 1.09 & 1.6 & 16,590 & $0.64^{\circ}$ & -4.5 & 2.2 & 2 & 3 & 1.7 \\
\hline Canada & 1.68 & 26.5 & 19,650 & $16.25^{\circ}$ & 3.4 & 0.8 & 29 & 32 & 0.4 \\
\hline $\begin{array}{l}\text { United } \\
\text { States }\end{array}$ & 1.50 & 250.0 & 21,360 & $136.88^{\circ}$ & 3.4 & 0.8 & 271 & 307 & 0.5 \\
\hline Denmark & 1.18 & 5.1 & 15,380 & $2.20^{\circ}$ & 2.4 & 0.0 & 5 & 5 & -0.1 \\
\hline W. Germany & 0.82 & 79.5 & 16,290 & $23.79^{\circ}$ & 2.1 & 0.1 & 80 & 78 & -0.1 \\
\hline Norway & 1.32 & 4.2 & 17.220 & 2.02 & 2.9 & 0.4 & 4 & 5 & 0.5 \\
\hline Swe den & 0.91 & 8.6 & 16,000 & $2.86^{\circ}$ & 2.2 & 0.3 & 9 & 9 & 0.1 \\
\hline Japan & 0.91 & 123.5 & 16,950 & $41.02^{\circ}$ & 4.1 & 0.3 & 127 & 128 & 0.0 \\
\hline Finland & 1.09 & 5.0 & 15,620 & $1.99^{\circ}$ & 3.4 & 0.2 & 5 & 5 & -0.1 \\
\hline $\begin{array}{l}\text { Switzer- } \\
\text { land }\end{array}$ & 1.00 & 6.7 & 21,690 & $2.45^{\circ}$ & 2.2 & 0.4 & 7 & 7 & 0.0 \\
\hline
\end{tabular}




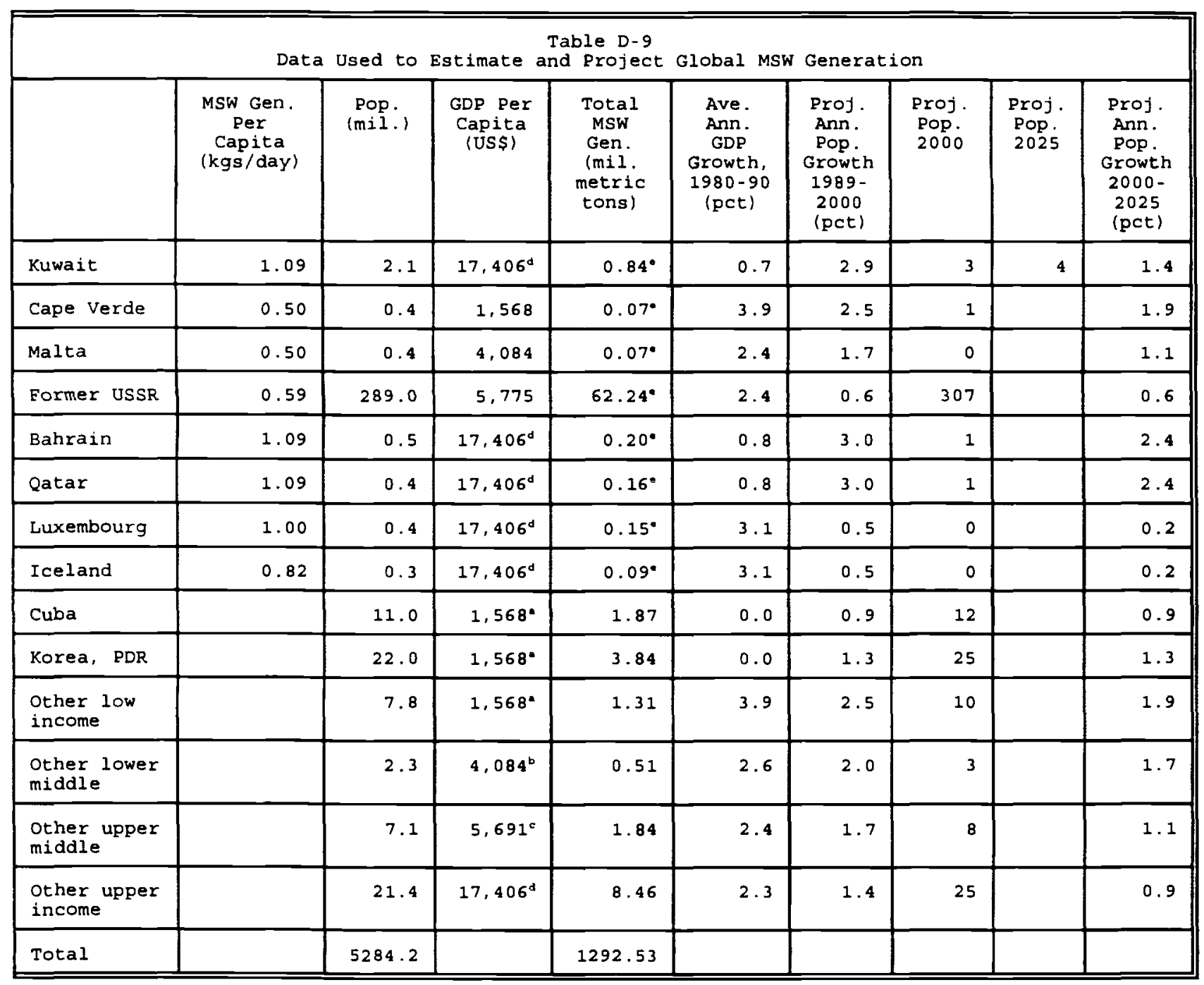

Notes:

Population-weighted average PPP-adjusted income for low-income countries.

bopulation-weighted average PPP-adjusted income for lower-middle-income countries.

Population-weighted average PPP-adjusted income for upper-middle-income countries

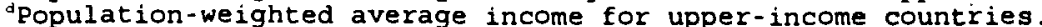

Based on actual MSW generation estimates (not fitted values from regression in table 1). 


\section{NOTES}

1. The "municipal" in municipal solid waste refers to the fact that the focus is on waste generated by communities as opposed to, say, isolated farms, which can generally dispose of waste on site without imposing costs on neighboring households or ecosystems.

2. More specifically, materials balance analysis estimates the weight of the domestic output of nondurable goods (minus net exports) and of discards of durable goods (based on past domestic production minus net exports and on estimated product lifetimes) adjusted for an estimate of permanent diversions from the waste stream. Examples of permanent diversions are paperboard used in construction (because construction and demolition debris are not included in the EPA estimates) and sanitary papers disposed of in sewage systems (see U.S. Environmental Protection Agency 1992, pp. A-1 - A-4). Thus, materials balance analysis is akin to an input-output analysis of MSW generation.

3. The elasticities shown in table 1 are estimated coefficients in an ordinary least squares regression of MSW generation on per capita gross domestic product (GDP) and population, where both the dependent and independent variables are measured in natural logarithms. We used the United Nations' International Comparison Project (ICP) estimates of GDP per capita, which are adjusted for cross-national differences in the purchasing power of local currency (World Bank 1992, pp. 276-77, 287-88).

4. MSW figures for an additional fourteen countries could not be used in the regression analysis because the World Development Report 1992 (World Bank 1992) did not report ICP estimates of per capita GDP for these countries.

5. Per capita daily MSW generation appears to be at least $0.3-0.4$ kilograms for even the poorest individuals within a country.

6. One might naturally expect MSW to have a unit population elasticity, that is, a 1.0 percent increase in population should be associated with a 1.0 percent increase in MSW generation holding per capita income fixed. In other words, if we compared two economies with the same per capita income, but one economy has twice the population of the other, then we might reasonably expect the larger economy to generate about twice as much MSW as the smaller economy.

7. Shafik and Bandyopadhyay (1992, p. 48) report an estimate of 0.38 for the income elasticity of MSW (with the population elasticity effectively constrained to equal 1.0) using a similar data set for 1985. We expect that MSW generation would be inelastic with respect to income, because MSW generation is likely to be proportional to consumption, and numerous empirical studies have found that consumption is income inelastic. Moreover, the share of 
services in consumption expenditures appears to rise with income, which reinforces the hypothesis that MSW generation should be inelastic, because the MSW intensity of goods consumption is greater than the corresponding intensity of services consumption.

8. We used the ICP estimates of GDP per capita reported for each country with a population greater than 1 million from World Bank 1992, pp. 276-77 and gross national product (GNP) per capita estimates for countries with populations of less than 1 million (World Bank 1992, p. 285) if these were available. We computed the average (weighted by population) of the ICP estimates of GDP per capita for countries within the income classifications (i.e., lowincome, lower-middle-income, upper-middle-income, and high-income economies) used in World Development Report 1992 and used these averages for those countries whose GDP or GNP per capita were not available. We classified Cuba and the People's Democratic Republic of Korea as low-income countries in accordance with their classification in World Development Report 1993 (World Bank 1993) and computed an estimate for per capita income in the former Soviet Union by computing the average (weighted by population) 1991 estimated GDP per capita of the countries that constituted the former Soviet Union using estimates from the same source.

9. We used the regression coefficient estimates to calculate fitted values for MSW generation for those countries for which there are no published MSW data. We then summed the fitted values (and the published MSW data if available) across the countries to arrive at our global estimate of MSW generation.

10. We used each country's reported average annual GDP growth rates from 1980 to 1990 to form our post-1990 projections of GDP (World Bank 1992, pp. 220-21). For our projections of country population growth we used the projected average annual growth rates for 1990 2000 and population levels in 2025 published in World Bank 1992, pp. 268-69; we assumed that the projected average annual population growth rates from 2000 to 2025 hold for the years after 2025. For those countries for which annual GDP or population growth rates were not reported, we used the average (weighted by population) growth rates for the income group to which the countries belonged (see endnotes 8 and 9).

11. We may gain a different perspective, however, by estimating how much land the world's annual output of MSW would occupy if it were all landfilled to a height of 100 meters, considerably less than the planned height of the Fresh Kills landfill in New York City (Rathje and Murphy 1992, p. 2). The result is slightly more than 28 square kilometers, if we assume that the density of the world's discarded MSW is the same as that of the United States, that is, 460 kilograms per cubic meter (see table 4). In other words, it would take nearly 100 years for a landfill containing the entire planet's MSW at current generation rates (without accounting for population or per capita income growth) to cover the entire state of Rhode Island, which represents only two-thousandths of 1 percent of the world's land area. (See Wiseman 1993, pp. 444-45 for a similar calculation for the MSW generated by the United 
States). Since discarded MSW is much more dense in developing countries than in the United States, our estimate may overstate global landfill land area requirements. Obviously, both the weight and the volume of discarded MSW are important determinants of the cost of collecting, transporting, and disposing of MSW.

12. See Rathje and Murphy 1992, pp. 101-2 and Alexander 1993, pp. 80-1 for a description and analysis of trends in materials substitution and technological innovations in the manufacture of containers and packaging in the United States. Both studies attribute these trends to market forces and not to government regulation.

13. For the Chinese city regressions we used per capita GDP for each city as the measure of per capita income. For the U.S. state regressions we used average personal income in each state rather than state GDP per capita, because cross-state commuting of workers renders GDP per capita a poor measure of the income of state residents, which is likely to be more closely associated with household generation of waste. Out of fifty states plus the District of Columbia, we dropped fourteen states whose waste generation figures included wastes other than commercial, residential, and institutional, namely, construction and demolition debris, sewage sludge, and industrial wastes. A similar regression for twenty-seven states, not all of which were included in the 1992 regression, using 1991 data yielded an income elasticity estimate of 0.72 (results not shown) as well as unit population elasticity. As another example (not based on regression analysis), daily per capita MSW generation is about 0.15 to 0.20 kilograms higher in Mexico City than in the poorer towns and medium-size cities in the rest of Mexico.

14. As population equals the product of average household size and the number of households, we explored whether variation in these variables influences the level of MSW generation independently of population and per capita income using both the U.S. crosssection and time series data (sufficient data were not available for other countries). From 1970 to 1990 , the size of the average household in the United States declined from 3.14 to 2.63 persons, and in 1990 ranged from 2.26 persons in the District of Columbia to 3.15 persons in Utah (U.S. Bureau of the Census 1993, pp. 55, 58). One might expect that declining average household size would be associated with rising per capita MSW generation, as there may economies of scale in household consumption. In other words, comparing two economies with the same per capita income, one with 1.0 million households and an average of two persons per household and the other with 0.5 million households and an average of four persons per household, per capita consumption of newspapers and magazines (major components of MSW in the United States) is likely to be lower in the latter economy than in the former. We found a negative relationship between household size and MSW generation in the cross-section analysis, but not in the time series analysis. However, in both cases the data do not allow us to reject the hypothesis that average household size exerts an influence on MSW generation that is statistically different from the influence of population. 
15. Some MSW management systems ignore or incompletely implement one or more of these key components. For example, typically only 50 to 70 percent of MSW is collected in developing-country cities (Cointreau-Levine 1994, p. 7).

16. Although not directly relevant to decision-making about MSW management options, it is worth noting that MSW collection workers in developing countries are one-third to one-half as productive as their counterparts in industrialized countries (Cointreau-Levine 1994, p. 13). Part of the difference in labor productivity may be due to the use of handcarts, donkey carts, and open trucks in developing countries, which are more labor intensive (Cointreau-Levine 1994, pp. 12, 28); in contrast, compaction collection vehicles that require two workers (a driver and a loader) or hauled container systems (which only require one worker) are commonly used in the United States (Tchobanoglous, Theisen, and Vigil 1993, pp. 204-210). Other sources of the difference in labor productivity may be larger average body size (and hence greater physical strength and stamina), better nutrition, better access to health care, and the more temperate climate that MSW collection workers in developed countries typically enjoy compared with their counterparts in developing countries.

17. For example, the Zabbaleen in Cairo provide MSW collection services in exchange for the opportunities to extract recyclable materials from the MSW for sale to manufacturing plants and to use food wastes as animal feed (Cointreau-Levine 1994, p. 28). Notably, the Zabbaleen formerly did not collect MSW from low-income areas since it contained little recyclable material (Cointreau-Levine 1994, p. 29), perhaps because low-income households do more recycling themselves.

18. For example, the proportion of official work time used by MSW collection workers for sorting recyclables has been observed to range from 10 percent in Mexico City to 40 percent in Bangkok. In Manila, MSW collection workers routinely take with them on their routes informal sector scavengers who pick out and sell recyclable materials and share the proceeds with the collection workers (Cointreau-Levine 1994, p. 11). Large numbers of children work as scavengers under extremely harsh conditions at the Smokey Mountain dump in Manila, until an International Labour Office program was established to provide the children with schooling and health care and alternative employment opportunities (Gunn and Ostos 1992).

19. It is estimated that there are about $8,000,10,000$, and 7,000 scavengers working at the MSW dumps in Jakarta, Mexico City, and Manila, respectively (Cointreau-Levine 1994, p. 32).

20. The following description of recycling systems in industrial countries is based on Spencer (1994). Kreith (1994a, chapter 9) is an excellent reference on the technology and economics of capital-intensive recycling systems. 
21. See Bennett, et al. 1992 for details of a project in Jakarta that developed a highly laborintensive composting technique. In the course of developing the technique, researchers experimented with a more capital-intensive forced aeration static-pile technique (in order to avoid the labor-intensive process of turning windrows) that was quickly rejected as economically inefficient.

22. Singapore's Environment Ministry claims that recycling materials other than paper and metal cans is not viable and that capital-intensive incineration to produce energy, conserve on landfill space, and recover some metals is more cost-effective (The Straits Times 1994).

23. The MSW generation rate shown for the United States is net of materials recovered for recycling or composting. The rates for the other countries are based on discards by households and firms (that is, net of materials they recover for recycling) but may include some recyclable materials that are recovered by scavengers and collection workers.

24. A comparative study of MSW in Mexico City and the United States found that Mexican households consumed relatively less processed and packaged foods and discarded relatively higher amounts of food waste. An estimated $\$ 1.4$ million worth of food (1980 dollars) was discarded each day in Mexico City in 1980, which is attributed to poor refrigeration and storage facilities in low-income Mexican households and to the low cost of food staples because of heavy government subsidies (Rathje, Reilly, and Hughes 1985, pp. x and 44-45). In the United States, factories that produce packaged foods generally recycle their discarded peels into animal feed or incinerate them to produce energy (Ibid., p. 36), which suggests that relatively low household food waste in the United States does not simply reflect a shift of these discards to industrial waste.

25. Notably, a study using data from 27 countries found a negative and statistically significant correlation between packaging waste and food waste: additional kilograms of plastic and paper packaging were associated with 1.1 and 0.7 fewer kilograms of food waste, respectively (Alter 1989).

26. Recent research suggests that the conversion of MSW into transport fuels such as methanol may be economical in the northeast United States, where MSW landfill tipping fees might run as high as US\$77-110 per metric ton. The only commercial operation in the world that converts MSW into transport fuels is operating in Italy, using a process that generates very low air emissions. As currently formulated, these processes are likely to yield less fuel in developing countries, where MSW contains less paper and wood and more moisture than in industrial countries. Moreover, tipping fees are likely to be lower in developing than in industrial countries, making these processes less likely to be economically efficient (Chen 1995). 
27. Arid regions can conserve water by using compost in agriculture; thus there is a trade off in deciding how best to use scarce water resources in these regions.

28. For example, a study of $340 \mathrm{MSW}$ collection operations in the United States found that average collection costs per ton of MSW declined as the scale of operations increased to service for 50,000 persons. Moreover, the average cost of service did not change when the service population exceeded 50,000 (Stevens 1977, p. 445).

29. Suburbanization is typically measured by the population density gradient, which is the average percent decrease in population density per unit of distance from the urban core. A decline in the density gradient for a metropolitan area generally implies that suburbanization has advanced. Average density gradients have been declining in developed countries over the past century and a half, while the decline in developing countries became widespread since World War II (Mills and Tan 1980, pp. 313-314 and 320).

30. For example, Taiwan is increasingly turning to incineration, presumably because of prohibitively high land acquisition costs for landfills.

31. Cointreau-Levine $(1994$, p. 17) suggests that there may be considerable economies of scale in transfer stations, especially if compaction devices are used to fill tractor-trailer trucks, a type of transfer station used, for example, in Bogota, Colombia (Tchobanoglous, Theisen, and Vigil 1993, p. 334). Building enough throughput capacity to minimize the time that collection vehicles must wait to unload can help keep down transportation costs.

Locating transfer stations near the weighted center of individual MSW generators and near major transportation routes also helps to lower hauling costs per ton of MSW, but these savings must be traded off against community and environmental protests. These objections may be appeased by designing enclosed transfer stations to reduce odors and the possibility that wind may blow trash out of the facility and by careful monitoring to ensure that MSW does not accumulate at the facility for more than several hours (Tchobanoglous, Theisen, and Vigil 1993, pp. 353-355). World Bank projects in Calcutta and Lagos encountered difficulties and delays in acquiring land with economic, environmental, and political features suitable for transfer station sites (Bartone, Bernstein, and Wright 1990, p. 20). The cost of siting these facilities probably does not double when their planned throughput capacity doubles, so siting problems may lead to fewer but larger facilities.

32. The installed capital cost of incinerator emission control systems appears to decline sharply as the daily capacity of facilities rises from about 500 metric tons to 1,000 metric tons, and levels off for facilities with greater than 1,500 metric tons per day (Teller 1994, p. 11.167).

33. A disability-adjusted life year, a measure of the burden of disease, represents the present value of future years of disability-free life that are lost because of premature deaths or cases 
of disability that occur in a particular year (World Bank 1993).

34. Doing so comes at a cost, because it sacrifices landfill capacity, although this cost could be lessened by using relatively low-quality composted MSW as the daily cover, which may be even more cost-effective in areas where soil suitable for landfill cover is not available (Tchobanoglous, Theisen, and Vigil 1993, p. 476, 448-52).

35 . The disease burden directly attributed to the tropical cluster diseases represents 2.4 percent of the disease burden attributable to all household environmental problems, 2.2 percent of the burden from infectious and parasitic diseases, and 0.7 percent of the overall disease burden in less developed countries.

36. More recently, regulations that restrict the disposal of hazardous waste in MSW landfills have led to lower concentrations of harmful compounds in leachate in new landfills in the United States (Tchobanoglous, Theisen, and Vigil 1993, p. 419).

37. In the United States, household hazardous wastes account for less than one percent of MSW by weight. Before the most recent set of federal MSW landfill regulations went into effect, firms that generated less than 100 kilograms of hazardous wastes per month could dispose of these wastes in MSW landfills, but these wastes also amounted to less than one percent (by weight) of all MSW going to landfills. However, before the Resource Conservation and Recovery Act of 1976 went into effect, federal restrictions on hazardous waste disposal in MSW landfills were weak, although states could impose stricter regulations (U.S. Congress 1989, pp. 86-90)

38. An estimated 940,000 metric tons of methane were recovered for fuel use in the United States in 1990, up from 300,000 metric tons in 1985 (U.S. Department of Energy 1993, p. 36).

39. Respiratory infections, chronic respiratory diseases, and respiratory tract cancers attributable to indoor air pollution are estimated to impose an annual burden of 164 million disability-adjusted life years on developing countries, or nearly 14 percent of their total disease burden (World Bank 1993, pp. 90, 215).

40. Nelson, Genereux, and Genereux (1992) also provide a thoughtful review of studies that estimate housing price gradients. Another study (Bleich, Findlay, and Phillips 1991) found that homes located near a strictly regulated MSW landfill did not command significantly lower prices than comparable homes located farther from the landfill; however, the landfill and its access roads were located on the other side of a hill adjacent to the neighborhood that was the target of the study, so the landfill and its associated activity were not visible from the target neighborhood. In contrast, the landfill and surrounding houses in the Nelson, Genereux, and Genereux study were on relatively flat and lightly wooded terrain, which may explain that study's finding of a negative impact on housing prices. 
41. See Portney (1994). For more details on the intricacies of the contingent valuation method see Mitchell and Carson (1989). Two recent articles, Hanemann (1994) and Diamond and Hausman (1994), debate the strengths and weaknesses of using the contingent valuation method. Remarkably, an exhaustive bibliography of 1,672 contingent valuation studies listed only 3 whose titles suggested that they focused on MSW management (Carson and others 1994).

42. Some anecdotally reported exceptions: a community in Costa Rica agreed to raise its own MSW management service fees by 300 to 400 percent in exchange for dependable service, and residents of a squatter community in Tegulcigalpa, Honduras, agreed to bring their MSW to a common collection site and pay a flat community fee in exchange for reliable, weekly collection by trucks (Ohnesorgen 1993, pp. 10-11).

43. For example, the residents of Seattle pay a fee for each uniform size can of MSW that they put out for collection. This has led to the "Seattle stomp" as residents try to compress as much MSW in a can as possible to minimize their collection fees (Richards 1993).

44. Under narrowly defined conditions (see Coase 1960), the disposal of MSW might not generate any negative externalities and therefore may not require government intervention to improve social welfare. Consider two neighboring households, A and B. Suppose household A dumps its MSW onto the property of household $B$, and suppose further that all adverse consequences resulting from A's dumping of its MSW are visited on B (that is, no other persons experience health or aesthetic problems associated with A's dumping of its MSW). Then if B has well-defined legal rights as a victim of MSW dumping, B can bargain for a payment from A that compensates $B$ for the damages caused by A's dumping. Likewise, if A has well-defined legal rights to dump its MSW, then A can bargain for a payment from B that compensates A for foregoing the right to dump on B's property. In either case, an optimal result is achieved without direct government intervention. Nevertheless, such an outcome is unlikely to occur, for the following reasons. First, except for extremely isolated rural households, the adverse consequences of open dumping of MSW are not confined to a small area that only affects one party. As more victims and dumpers are involved, it becomes more costly to negotiate, monitor, and enforce compensatory contracts between all of the parties, creating incentives for free riding which undermine the contracts (Baumol and Oates 1988, p. 10). Second, all households generate MSW, creating opportunities for presumably inefficient retaliation (household B could dump its MSW onto household A's property). Finally, the preferences of future generations that may be adversely affected by open dumping of MSW might not be taken into account when victims and dumpers negotiate compensatory payments, resulting in a suboptimal outcome.

45. The study used data on MSW collection charges and tonnage of waste collected and landfilled by a sample of fourteen communities in the United States between 1980 and 1989. Ten of the communities levied curbside collection charges. The results of the study suggest 
that a US\$1.50 charge per thirty-two-gallon container (which typically holds about 9.5 kilograms) would induce households to cut the waste they put out for collection by an average of 18 percent per capita ( 0.2 kilograms per capita per day). If the fees were combined with a program for collecting recyclable materials from households, then the average reduction increased to more than 30 percent (Repetto and others 1992, p. 18).

46. Cyprus, Egypt, India, Lebanon, and Syria have deposit-refund systems for carbonated beverage containers made of glass; Australia, Canada, France, Germany, Switzerland, and the United States have deposit-refund systems for various types of beverage containers; and the Scandinavian countries are considering deposit-refund systems for certain products containing mercury and cadmium, such as batteries (King, Crosson, and Shogren 1993, p. 74). Whether the benefits of these programs, including aesthetic benefits, exceed their costs, including the opportunity cost of households' time, is not entirely clear (see, for example, Porter 1978).

47. Santiago, Caracas, Sao Paolo, and Rio de Janeiro all bill households for MSW services based on the municipalities' past MSW management costs. Because of low inflation in Chile, Santiago's MSW manangement fees have been in line with current MSW management costs. In the other cities, accelerating inflation has led to consistent underestimates of MSW management costs, and as a result MSW management fees have only covered between 10 and 70 percent of program costs (Bartone and others 1991, p. 505).

48. These figures include payments by households to private MSW collection and disposal businesses; local, state, and federal government spending on publicly provided service; and fees paid by governments to private MSW management contractors to provide services to households, government agencies, and perhaps other entities. They do not include expenditures by enterprises and institutions other than households and governments, which account for between 35 and 45 percent of MSW generation in the United States (U.S. Environmental Protection Agency 1992, p. 5-3). The federal government provides virtually no MSW collection and disposal services to entities other than federal agencies.

49. A 1975 study estimated that between one-third and one-half of all households in the United States had their MSW collected by private firms (Donahue 1989, pp. 58, 230). By contrast, corresponding estimates for the early 1990s range as high as 80 percent (McAdams 1994, p. 44). In 1991, an estimated 343,000 people were employed in collection, transport, and disposal of MSW, of which about two-thirds were employed in private firms (U.S. Bureau of the Census 1993, p. 228, 1991, table 10).

50. Effective October 9, 1993, the U.S. Environmental Protection Agency's Municipal Solid Waste Landfill Criteria took effect. These regulations impose restrictions on the location of new landfills; require a daily cover of six inches of soil on landfills; require owner/operators of landfills to check for and remediate methane emissions; largely prohibit the open burning 
of waste; mandate owner/operators to build and maintain control systems for storm water runon/runoff; set maximum contaminant levels for groundwater as a basis for design of new landfills (which can be met by lining landfills with a layer of impermeable material two feet thick plus a synthetic flexible membrane barrier and a leachate collection system); and requires owner/operators to file plans for closure of the landfill (including a two-foot earthen cover) and for thirty years of postclosure maintenance of the final cover, monitoring ground water and methane gas, and continuing leachate management (U.S. EPA 1993). The U.S. Office of Technology Assessment estimates that pollution controls increase the average MSW disposal cost to US\$20 compared with US\$9 (in 1988 U.S. dollars) for landfills with no pollution controls (U.S. Congress 1989, p. 62), although it is likely that the cost of pollution controls vary with regional differences in hydrogeology. These requirements appear to have evolved in response to various side-effects of earlier attempts to limit the environmental problems associated with landfills (see Ham 1993). In the 1960s landfills began to be sited away from surface waters and wetlands to avoid surface water contamination. In the early 1970s groundwater contamination led to requirements that landfills be located in areas with low water tables and tight soils (fine silts and clays) or be lined with clay. By the mid-1970s experts realized that these requirements led to leachate accumulation within landfills and leakage into surrounding areas, so leachate collection and treatment systems were required. As these systems are costly, landfill operators tried to limit the entry of water into landfills by using clay or plastic membrane caps. Unfortunately, this practice prevented the venting of methane and posed a danger of explosion, so by the mid-1980s methane was collected for flaring or for use. As excluding all water from landfills is impossible, some decomposition will occur anyway. Consequently, monitoring of leachate and gases must take place for many years, even after a landfill is closed; a costly endeavor that many developing countries cannot afford. Increasingly strict state, and more recently federal landfill regulations have led to many landfill closures and a great deal of concern in the late 1980s about future landfill capacity. About 14,000 landfills have been closed in the United States since 1978, leaving about 6,000 in operation. Many of landfills that were shut down were open dumps and were relatively small, while the landfills still in operation are much larger (Rathje and Murphy 1992, p. 106).

51. Prices for recyclable materials have risen recently because of rising demand springing from new plants capable of recycling old newspapers and other materials, mandated use of recycled paper by government agencies, and high prices for virgin materials resulting from the global economic recovery (Pressler 1995). Moreover, as noted below, landfill tipping fees have been declining recently, implying that cost savings from recycling because of the avoided cost of landfilling are also declining. Finally, curbside collection of recyclable materials adds considerably to the overall cost of MSW collection (Kreith 1994, p. 1.13). Even advocates of recycling acknowledge that prices for recyclable materials have not risen to the point where curbside recycling programs are profitable, requiring that a judgment of whether the benefits outweigh the costs depends on avoided nonpecuniary environmental costs (Pressler 1995, p. A14). 
52. We regressed the percent of persons in each country covered in the Gallup survey who believed that "inadequate sewage, sanitation and garbage disposal" was a "very serious" problem on a dummy variable indicating whether or not the country was industrialized and the percent population living in urban areas. We found no systematic relationship between urbanization and the perception of poor sanitation services. This finding suggests that on the whole MSW management is not perceived to be worsening with urbanization.

53. In contrast, recycling programs for aluminum and tin cans, glass, batteries, and tires have relatively low participation rates, because these programs are not as convenient as the plastic bottle deposit-refund program (Republic of China 1993, p. 254).

54. This glossary relies heavily on the more comprehensive glossary that appears in Kreith (1994a, pp. A.1-A.21). Another excellent glossary appears in Tchobanoglous, Theisen, and Vigil (1993, pp. 905-12). 


\section{REFERENCES}

Alexander, Judd H. 1993. In Defense of Garbage. Westport, Connecticut: Praeger.

Alter, H. 1989. "The Origins of Municipal Solid Waste: The Relations between Residues from Packaging Materials and Food." Waste Management \& Research 7: 103-14.

. 1991. "The Future Course of Solid Waste Management in the U.S." Waste Management \& Research 9: 3-20.

Bailey, Jeff. 1992. "Space Available: Economics of Trash Shift as Cities Learn Dumps Aren't so Full." The Wall Street Journal (June 2):A1.

. 1993a. "Up in Smoke: Fading Garbage Crisis Leaves Incinerators Competing for Trash." The Wall Street Journal (August 11):A1.

. 1993b. "Poor Economics and Trash Shortage Force Incineration Industry Changes." The Wall Street Journal (August 11):A2.

Bartone, Carl R., and Janis D. Bernstein. 1993. "Improving Municipal Solid Waste Management in Third World Countries." Resources, Conservation and Recycling 8:4354.

Bartone, Carl R., Janis D. Bernstein, and Frederick Wright. 1990. Investments in Solid Waste Management: Opportunities for Environmental Improvement. Policy, Research, and External Affairs Working Paper No. 405. Washington, DC: World Bank, Infrastructure and Urban Development Department.

Bartone, Carl R., Luiz Leite, Thelma Triche, and Roland Schertenleib. 1991. "Private Sector Participation in Municipal Solid Waste Service: Experiences in Latin America." Waste Management \& Research 9:495-509.

Baumol, William J., and Wallace E. Oates. 1988. The Theory of Environmental Protection. Cambridge, England: Cambridge University Press.

Benavides, Livia. 1992. "Hazardous Waste Management for Small-Scale and Cottage Industries in Developing Countries: Overview Paper." United Nations Development Programme, Urban Management Program, United Nations Center for Human Settlements, and World Bank. Processed. 
Bennett, Christopher P. A., David E. Bloom, Lakshmi Reddy Bloom, Marguerite S. Robinson, and Michael H. Simpson. 1993. Enterprises for the Recycling and Composting of Municipal Solid Waste. Jakarta: Center for Policy and Implementation Studies.

Bowen, Richard C., and Robert N. Lambe. 1994. "Analyzing the Costs of Remediation Options." Best's Review (January):70-72.

Carson, Richard T., Jennifer Wright, Anna Alberini, Nancy Carson, and Nicholas Flores. 1994. A Bibliography of Contingent Valuation Studies and Papers. La Jolla, California: Natural Resource Damage Assessment, Inc. (March).

Chen, Jeffrey S. 1995. Methanol and Hydrogen Production from Municipal Solid Waste. Masters of Science in Engineering Thesis, Princeton University.

Coase, R. H. 1960. "The Problem of Social Cost." Journal of Law and Economics 3:1-44.

Cointreau, Sandra Johnson, Charles. G. Gunnerson, John M. Huls, and Neil N. Seldman. 1984. Recycling from Municipal Refuse: A State-of-the-Art Review and Annotated Bibliography. World Bank Technical Paper Number 30. Washington, DC: World Bank.

Cointreau-Levine, Sandra J. 1994. Private Sector Participation in Municipal Solid Waste Services in Developing Countries, vol. 1, The Formal Sector. Washington, DC: World Bank.

DeLong, James V. 1994. "Of Mountains and Molehills: The Municipal Solid Waste 'Crisis'." The Brookings Review (Spring):32-39.

Diamond, Peter A. and Jerry A. Hausman. 1994. "Contingent Valuation: Is Some Number Better than No Number?" Journal of Economic Perspectives 8(Fall):45-64.

Diaz, L. F., G. M. Savage, and C. G. Golueke. 1994. "Composting of Municipal Solid Wastes." In Frank Kreith, ed., Handbook of Solid Waste Management New York: McGraw-Hill.

Donahue, John D. 1989. The Privatization Decision: Public Ends, Private Means. New York: Basic Books.

Dunlap, Riley E., George H. Gallup, Jr., and Alec M. Gallup. 1993a. Health of the Planet. Princeton: Gallup International Institute. 
. 1993b. "Of Global Concern: Results of the Health of the Planet Survey." Environment 35:7-13, 33-39(November).

Economic Report of the President January 1993. Washington, DC: U.S. Government Printing Office.

Elkington, John, and Jonathan Shopley. 1989. Cleaning Up: U.S. Waste Management Technology and Third World Development. Washington, DC: World Resources Institute.

Fullerton, Don, and Thomas C. Kinnamon. 1993. "Garbage, Recycling, and Illicit Burning or Dumping." Working Paper No. 4374. Cambridge, Massachusetts: National Bureau of Economic Research.

Gunn, Susan E., and Zenaida Ostos. 1992. "Dilemmas in Tackling Child Labour: The Case of Scavenger Children in the Philippines." International Labour Review 131:629-646.

Ham, Robert K. 1993. "Overview and Implications of U.S. Sanitary Landfill Practice." Air \& Waste 43 (February):187-90.

Hanemann, W. Michael. 1994. "Valuing the Environment Through Contingent Valuation." Journal of Economic Perspectives 8(Fall):19-43.

King, Dennis, Pierre Crosson, and Jason Shogren. 1993. "Use of Economic Instruments for Environmental Protection in Developing Countries." In Organization for Economic Cooperation and Development, ed., Economic Instruments for Environmental Management in Developing Countries. Paris: Organization for Economic Cooperation and Development.

Frank Kreith, ed. 1994a. Handbook of Solid Waste Management. New York: McGraw-Hill.

Kreith, Frank. 1994b. "Introduction." In Frank Kreith, ed. Handbook of Solid Waste Management. New York: McGraw-Hill.

McAdams, Cheryl L. 1994. "Contracting for Waste Services Becoming Palatable Remedy for Municipalities." Waste Age (April):44-46.

Meade, Kathleen. 1992. "Mexico City Moves Mountains of Waste." Waste Age (April):150-56.

Melosi, Martin V. 1981. Garbage in the Cities: Refuse, Reform, and the Environment, 18801980. College Station, Texas: Texas A\&M University Press. 
Mensah, Joseph, and Herbert A. Whitney. 1991. "Some Third World Environmental Perceptions and Behaviours Concerning Urban Waste: A Survey of Techiman, Ghana." The Canadian Geographer 35:156-65.

Mills, Edwin S., and Peter Mieszkowski. 1993. "The Causes of Metropolitan Suburbanization." Journal of Economic Perspectives 7 (Summer):135-47.

Mills, Edwin S., and Jee Peng Tan. 1980. "A Comparison of Urban Population Density Functions in Developed and Developing Countries." Urban Studies 17:313-21.

Mitchell, Robert and Richard Carson. 1989. Using Surveys to Value Public Goods: The Contingent Valuation Method Washington, D.C.: Resources for the Future.

Muttamara, S., C. Visvanathan, and K.U. Alwis. 1992/93. "Solid Waste Recycling and Reuse in Bangkok." Environmental Systems Reviews (33).

Nelson, Arthur C., John Genereux, and Michelle Genereux. 1992. "Price Effects of Landfills on House Values." Land Economics 68 (November):359-65.

O'Connor, David. 1993. "The Use of Economic Instruments in Environmental Management: The Experience of East Asia." In Organization for Economic Cooperation and Development, ed., Economic Instruments for Environmental Management in Developing Countries. Paris: Organization for Economic Cooperation and Development.

Ohnesorgen, Frank. 1993. "Sorting Out Solid Waste: Developing Countries Need Management Expertise." Public Management 75(March):9-12.

Oster, Patrick. 1989. The Mexicans. New York: Harper \& Row.

Porter, Richard. 1978. "A Social Benefit-Cost Analysis of Mandatory Deposits on Beverage Containers." Journal of Environmental Economics and Management 5:351-375.

Portney, Paul R. 1994. "The Contingent Valuation Debate: Why Economists Should Care." Journal of Economic Perspectives 8(Fall):3-17.

Pressler, Margaret Webb. 1995. "Turning Trash Into Cash: Rising Demand Aids Local Recycling Efforts." The Washington Post (February 8):A1.

Project 88 Round II. 1991. A public policy study sponsored by Senators Timothy E. Wirth and John Heinz and directed by Robert N. Stavins. Washington, DC. 
Rathje, William, and Cullen Murphy. 1992. Rubbish! The Archaeology of Garbage. New York: Harper Collins.

Rathje, William, Michael D. Reilly, and Wilson W. Hughes. 1985. Household Garbage and the Role of Packaging: The United States/Mexico City Comparison. Tucson, Arizona: Le Projet du Garbage.

Repetto, Robert, Roger C. Dower, Robin Jenkins, and Jacqueline Geoghegan. 1992. Green Fees: How a Tax Shift Can Work for the Environment and the Economy. Washington, DC: World Resources Institute.

Republic of China, Directorate-General of Budget, Accounting, and Statistics. 1992. Statistical Yearbook of the Republic of China 1992. Taipei, Taiwan (China).

. Government Information Office. The Republic of China Yearbook, 1993. Taipei, Taiwan (China).

Richards, Bill. 1993. "Trash Dance: Recycling in Seattle Sets National Standard but is Hitting Snags." The Wall Street Journal (August 3):A1.

Rutledge, Gary L., and Christine R. Vogan. 1994. "Pollution Abatement and Control Expenditures, 1972-1992." Survey of Current Business 74 (May):36-49.

Schneider, Keith. 1994. "Incinerator Operators Say Ruling Will Be Costly." The New York Times. (May 3):A18.

Shafik, Nemat, and Sushenjit Bandyopadhyay. 1992. "Economic Growth and Environmental Quality: Time-Series and Cross-Country Evidence." Background Paper for the World Development Report 1992. Washington, DC: World Bank.

Sicular, Daniel T. 1992. Scavengers, Recyclers, and Solutions for Solid Waste Management in Indonesia. Monograph No. 32. Berkeley, California: Center for Southeast Asia Studies, University of California at Berkeley.

Spencer, David B. 1994b. "Recycling, Part E." In Frank Kreith, ed., Handbook of Solid Waste Management. New York: McGraw-Hill.

State Statistical Bureau of the People's Republic of China. 1991. China Statistical Yearbook 1991. Beijing: China Statistical Information and Consultancy Service Center, International Center for the Advancement of Science and Technology Ltd. 
Steuteville, Robert and Nora Goldstein. 1993. "The State of Garbage in America: 1993 Nationwide Survey." BioCycle 34(Mayl):42-47.

Stevens, Barbara J. 1977. "Scale, Market Structure, and the Cost of Refuse Collection." Review of Economics and Statistics 60 (March):438-48.

The Straits Times. 1994. "Incineration Remains Best Way to Dispose of Waste, Says ENV." (April 26).

Tchobanoglous, George and Philip R. O'Leary. 1994. "Landfilling." In Frank Kreith, ed. Handbook of Solid Waste Management. New York: McGraw-Hill.

Tchobanoglous, George, Hilary Theisen, and Samuel Vigil. 1993. Integrated Solid Waste Management: Engineering Principles and Management Issues. New York: McGraw-Hill.

Teller, Aaron. 1994. "Waste-to-Energy Conversion." In Frank Kreith, ed. Handbook of Solid Waste Management. New York: McGraw-Hill.

Tietenberg, Tom. 1992. Environmental and Natural Resource Economics. New York: HarperCollins.

U.S. Bureau of Economic Analysis. "State Personal Income, Revised Estimates for 1991-93." 1994. Survey of Current Business. 74 (August):64-79.

U.S. Bureau of the Census. 1978. Statistical Abstract of the United States: 1978, 99th ed. Washington, DC: U.S. Government Printing Office.

1981. Public Employment in 1981. Series GE 81-1. Washington, DC: U.S. Government Printing Office.

. 1983. Statistical Abstract of the United States: 1984, 104th ed. Washington, DC: U.S. Government Printing Office.

1986. Statistical Abstract of the United States: 1987, 107th ed. Washington, DC: U.S. Government Printing Office.

1988. Public Employment in 1988. Series GE 88-1. Washington, DC: U.S. Government Printing Office.

1990. Statistical Abstract of the United States: 1990, 110th ed. Washington, DC: U.S. Government Printing Office. 
1991. Public Employment in 1991. Series GE 91-1. Washington, DC: U.S. Government Printing Office.

1993. Statistical Abstract of the United States: 1993, 113th ed. Washington, DC: U.S. Government Printing Office.

U.S. Congress, Office of Technology Assessment. 1989. Facing America's Trash: What Next for Municipal Solid Waste? OTA-O-424. Washington, DC: U.S. Government Printing Office.

U.S. Department of Energy, Energy Information Administration. 1993. Emissions of Greenhouse Gases in the United States: 1985-1990. DOE/EIA-0573. Washington, DC: U.S. Government Printing Office.

. Estimates of U.S. Biomass Energy Consumption. DOE/EIA-0548(92). Washington, DC: U.S. Government Printing Office.

U.S. Environmental Protection Agency. 1990. Characterization of Municipal Solid Waste: 1990 Update. Washington, DC: National Technical Information Service.

1992. Characterization of Municipal Solid Waste: 1992 Update. No. PB92-207166. Washington, DC: National Technical Information Service.

1993. Criteria for Solid Waste Disposal Facilities: A Guide for Owners/Operators. No. EPA/530-SW-91-089. Washington, DC: U.S. Government Printing Office.

Ward, Robert M., and Jinan Li. 1993. "Solid Waste Disposal in Shanghai." The Geographical Review (January):29-42.

Wiseman, A. Clark. 1992. "Government and Recycling: Are We Promoting Waste?" Cato Journal 12 (Fall):443-60.

The World Almanac 1993. New York: World Almanac.

World Bank. 1992. World Development Report 1992. New York: Oxford University Press. . 1993. World Development Report 1993: Investing in Health. New York: Oxford University Press.

World Resources Institute. 1993. The 1993 Information Please Environmental Almanac. Boston: Houghton Mifflin. 
Yhdego, Michael. 1988. "Urban Solid Waste Management in Tanzania." Waste Management \& Research 6:175-94. 1991. "Scavenging Solid Wastes in Dar es Salaam, Tanzania." Waste Management \& Research 9:259-65. 